\title{
Article \\ A Review of Maximum Power Point Tracking Algorithms for Wind Energy Conversion Systems
}

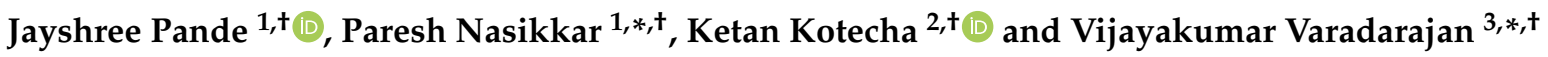 \\ 1 Symbiosis Institute of Technology, Symbiosis International (Deemed University), Pune 412115, Maharashtra, \\ India; jayshree.pande@sitpune.edu.in \\ 2 Symbiosis Centre for Applied Artificial Intelligence, Symbiosis International (Deemed University), \\ Pune 412115, Maharashtra, India; director@sitpune.edu.in \\ 3 School of Computer Science and Engineering, The University of New South Wales, \\ Sydney, NSW 2052, Australia \\ * Correspondence: paresh.nasikkar@sitpune.edu.in (P.N.); vijayakumar.varadarajan@gmail.com (V.V.) \\ + These authors contributed equally to this work.
}

Citation: Pande, J.; Nasikkar, P.; Kotecha, K.;Varadarajan, V. A Review of Maximum Power Point Tracking Algorithms for Wind Energy Conversion Systems. J. Mar. Sci. Eng. 2021, 9, 1187. https://doi.org/ $10.3390 /$ jmse 9111187

Academic Editor: Constantine Michailides

Received: 29 September 2021

Accepted: 21 October 2021

Published: 27 October 2021

Publisher's Note: MDPI stays neutral with regard to jurisdictional claims in published maps and institutional affiliations.

Copyright: (c) 2021 by the authors. Licensee MDPI, Basel, Switzerland. This article is an open access article distributed under the terms and conditions of the Creative Commons Attribution (CC BY) license (https:// creativecommons.org/licenses/by/ $4.0 /)$.

\begin{abstract}
Renewable energy resources are gaining a lot of popularity. Several researchers have worked on the tracking and extraction of energy from these sources. In the past few decades, among the available green energy resources, wind energy has been the most attractive option among the resources available. It is imperative to use the maximum power available in the wind to achieve the wind turbine (WT) operation at maximum power. The maximum power point tracking (MPPT) algorithms are a pioneer in this context. Many research papers are contributed in this domain which necessitates a thorough review while choosing an appropriate technique. This paper comprehensively focuses on reviewing different algorithms in the past and present for tracking maximum power point, and capturing maximized output power from the wind energy conversion system (WECS). In this paper, the algorithms are classified based on the direct and indirect power measurement, hybrid and smart algorithms for tracking maximum power point, and they are compared, considering the parameters like complexity, convergence speed, use of sensors, memory requirement, need for knowledge of system parameters, etc. The immense popularity of the different versions of perturb and observe $(\mathrm{P \& O})$ based algorithms due to their various features is evident from the literature. The review reveals that the hybrid maximum power point tracking algorithms can use the advantages of the conventional methods and eliminate their drawbacks.
\end{abstract}

Keywords: green energy; maximum power point tracking; wind energy conversion systems; wind turbine

\section{Introduction}

With the ever-increasing prices, the increasing need for conventional fuels, and the decline in their availability, renewable energy resources such as wind energy are gaining immense popularity. Moreover, it is a form of green energy that is environment friendly. Globally, a remarkable increase is observed in the installation of wind power plants consistently [1,2] as depicted in Figure 1. By the year 2022, the global installed wind capacity will reach $840 \mathrm{GW}$. The basic nature of wind being extremely fluctuating, the optimal speed of the generator has to be maintained to obtain maximum yield of energy from WECS. Therefore, tracking the MPP is very popular and extremely important for ensuring the maximum capture of energy from the WECS for different varying speeds of the wind. 


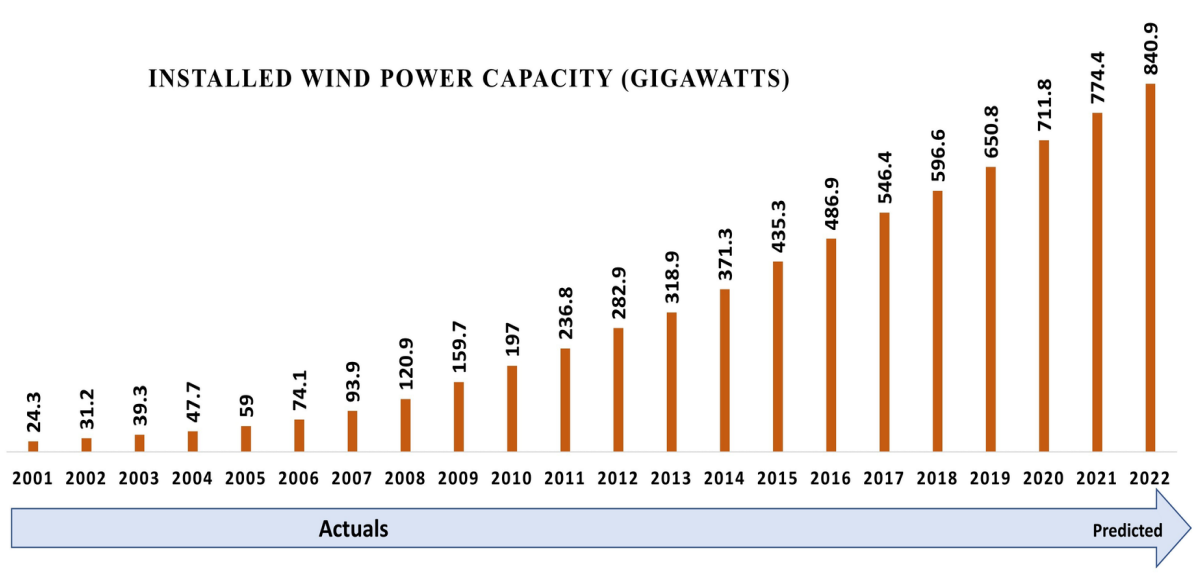

Figure 1. Globally installed wind power capacity. Reused with permission from Ref. [3]. Copyright 2021 Elesevier.

As portrayed in Figure 2, the kinetic energy present in the wind serves as an input to the WECS. The output of the WECS becomes fluctuating as the continuous changes in the speed of the wind influence it. The most important function of a WT is to provide mechanical energy by transforming the kinetic energy present in the wind, which can then drive the generator to produce clean electrical energy. Maximum energy extraction is possible for all variable speeds of the wind as the wind turbine with variable speed has a speed shaft that is adjustable $[4,5]$. WT's are categorized as the horizontal axis wind turbine (HAWT) and the vertical axis wind turbine (VAWT), considering their axis of rotation [6]. The axis around which the WT rotates in VAWT is at a right angle to the ground, while the remaining assembly is placed on the ground. The VAWT has various drawbacks, such as those related to the blade lift forces, and another major drawback is the problem of the lower capacity of generation $[7,8]$. On the other hand, there are considerable advantages of the HAWT such as better aerodynamic performance, drive train loading is balanced, and their cost is low. The three-blade design is the most prevalent in the present-day industry [9]. The WT's are also categorized as wind turbines with variable speed (VSWT) and wind turbines with fixed speed (FSWT). There are numerous issues with the FSWT, such as the huge mechanical stress, a limited range for speed of operation, and gear with multiple stages is required [10]. To overcome the drawbacks of the FSWT, the VSWT is preferred [11]. The main benefit of using the VSWT is obtaining maximum power for each wind speed along with reduced mechanical stress and power supply fluctuations [12-14]. 




Figure 2. Grid tied WECS general configuration. Reused with permission from ref. [3]. Copyright 2021 Elsevier.

There are various kinds of generators employed for the WECS. The Squirrel cage induction generators (SCIG's) can be counted as a low-cost, reliable, and simple option available for WECS [15]. Doubly fed induction generators (DFIG's) alternatively are also preferred for WECS as they are economical when used with the power converters. The only issue with them is the requirement of a multi-stage gearbox, and also they need excitation [16-18]. Finally, permanent magnet synchronous generators(PMSG's) are attracting researchers due to higher efficiency and reliability, better performance, and better fault ride-through (FRT) capability [19-22]. A review of the generators for WECS is given in $[10,11,17]$. From the available energy possessed by the wind, only $59 \%$ is extracted by the WT by Betz limit. Therefore, the power present in the air is given as in Equation (1).

$$
\text { Pair }=\frac{1}{2} \rho A V^{3}
$$

The density of air is represented by $\rho$, the area swept by the blades of the turbines is represented by $A$ in $m^{2}$, and the speed of the wind in $(\mathrm{m} / \mathrm{s})$ is represented by $V$. The tip speed ratio (TSR), represented by $\lambda$ is given as in Equation (2).

$$
\lambda=\frac{R * \omega}{V}
$$

$R$ represents the radius of the turbine blade, and $\omega$ represents the angular speed which is given in rad/s. The air density is a variable parameter that may change from season to season and can be different at different locations. $C_{p}$ represents the power coefficient. Its maximum value is given by Equation (3) and it is limited to less than $59 \%$ by the Betz limit.

$$
C_{p}=\frac{P_{\text {windturbine }}}{P_{\text {air }}}
$$

$P_{\text {windturbine }}$ represents the power absorbed by the WT from the wind, and $P_{\text {air }}$ represents the power present in the wind. The parameter $C_{p}$ is dependent on the values of $\lambda$ and the pitch angle $\beta$. The relation between $C_{p}$ and TSR is shown in Figure 3. From the graph, we can comment that the $C_{p}$ has the highest value $C_{p m a x}$ as 0.48 for a particular value of $\lambda$. This optimal value is useful in tracking the maximum power. 


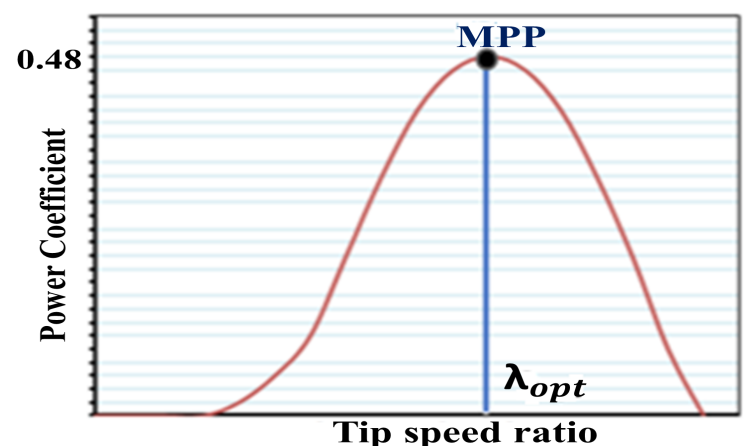

Figure 3. Relation between $C_{p}$ and TSR. Reused with permission from Ref. [23]. Copyright 2019 Elesevier.

Figure 4 depicts the different regions of operation for WECS and the region for MPPT. There is no generation for all the velocities below the cut-in value as it is the minimum required speed to start generating usable power. The speed at which rated usable power is generated is the rated speed. The maximum power is extracted in region two that lies between the $V_{\text {cutin }}$ and $V_{\text {rated }}$. Figure 5 portrays the relation between optimal values of $\lambda$ and $C_{p}$ and explains the concept of MPPT for WECS. Various MPPT controllers are described in the literature, and all of them operate in this region and capture the maximum amount of power contained in the wind. Hence, this region is crucially important while considering the maximum extraction of power. The major focus of the MPPT algorithms described in this paper is on this region of operation.

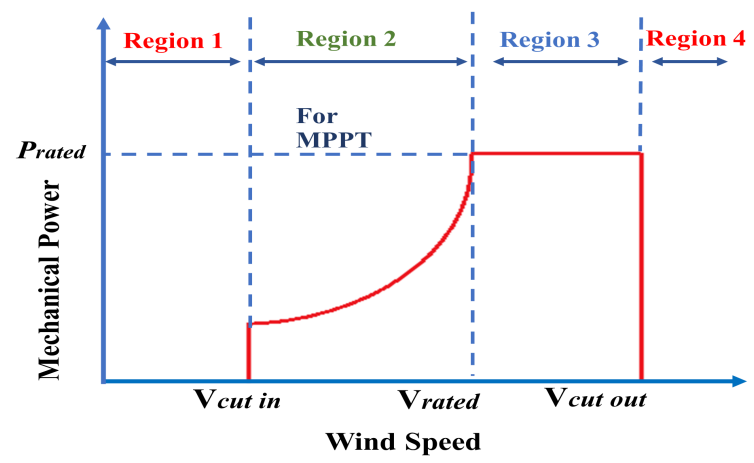

Figure 4. WECS operating regions. Reused with permission from Ref. [24]. Copyright 2019 Elesevier.

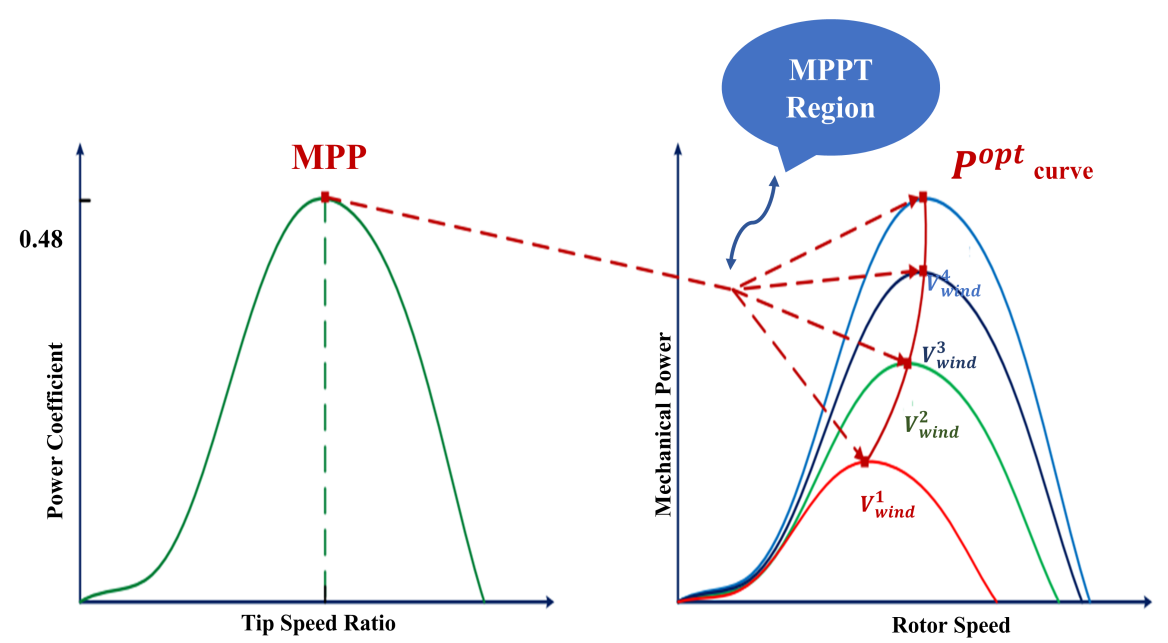

Figure 5. Characteristics of Wind Turbine Power under optimal values of $\lambda$ opt and $C_{\text {popt }}$. Reused with permission from Ref. [23]. Copyright 2019 Elsevier. 
The performance of WECS is affected by the control strategies that are employed. A review of the control strategies is presented in [25-27]. The control strategies are highly influenced by the integration of the MPPT algorithm for the WECS. Therefore, these advanced control techniques must produce minimum disturbances when these MPPT algorithms are implemented for WECS [28-31].

MPPT algorithms help in tracking and extracting maximum power from WECS. A large variety of algorithms are available. Based on the requirement of speed sensors for measurement of wind speed, MPPT methods employed are categorized into methods employing speed sensors and methods that do not employ speed sensors to estimate the speed of the wind. In the MPPT algorithms that use speed sensors for wind speed measurements, sensors such as anemometers are used. The MPPT algorithms such as tip speed ratio (TSR) and power signal flow (PSF) fall into the category of speed sensor based MPPT methods and perturb and observe (P\&O), optimal relation based (ORB), and incremental conductance (INC) fall under the category of MPPT algorithms that do not employ wind speed sensors. Different hybrid techniques are also available in the literature that enables overcoming the drawbacks of the conventional algorithms mentioned above, and they facilitate the capture of maximum from WECS as they are formed by merging two or more conventional techniques. Smart MPPT algorithms are also proposed in the literature based on intelligent techniques such as neural networks (NN) and fuzzy logic controller (FLC). Different hybrid algorithms are available, which are a combination of optimization algorithms and the conventional MPPT algorithms to get maximum power from WECS [32].

Many review articles have given a comprehensive review of the MPPT algorithms for WECS [32-37]. In this paper, various algorithms of the past and present are described that are used for tracking and obtaining maximum power output from WECS along with the description of the recent advancements in the $\mathrm{P} \& \mathrm{O}$ based modified versions and the smart and hybrid versions available in the literature. The algorithms are classified based on the direct and indirect power measurement, hybrid and smart MPPT algorithms, and they are compared concerning parameters such as complexity, convergence speed, use of sensors, memory requirement, need of prior knowledge of system parameters, etc.

The organization of the remaining part of the paper is as follows, Section 2 explains the concept of MPPT for WECS followed by the classification and description of the conventional, modified, smart and hybrid MPPT algorithms with their classification. The references are summarized for these methods. Section 3 presents the discussion, and the trends and future scope are discussed in Section 4 . A brief conclusion is presented for this study.

\section{MPPT Algorithms for WECS}

The basic objective behind using the MPPT algorithm is tracking and capturing maximum power from WECS. Different regions of operation for WECS and the region for MPPT are shown in Figure 4. We can very well understand the concept of MPPT from Figure 5. The MPP at every wind speed makes up the $P_{\text {opt }}$ curve. There is no generation for all the velocities below the cut-in value as it is the minimum required speed to start generating usable power. The speed at which rated usable power is generated is the rated speed. The maximum power is extracted in region two that lies between the $V_{\text {cutin }}$ and $V_{\text {rated }}$. Several important variables such as the voltage, optimal power, duty cycle have to be estimated that may be challenging as stated in $[23,32,36]$. For selecting the appropriate MPPT algorithm, among several parameters, efficiency, speed, need of wind speed sensors, implementation complexity is considered. MPPT algorithms find their applications in renewable energy systems such as solar PV, wind energy, and others.

MPPT algorithms designed in the past works use the parameters such as the TSR, relation between the turbine rotational speed and power, and many others mentioned above in the review of the past works. They essentially aid in tracking and extracting maximum power from WECS. In $[38,39]$ the classification of the MPPT algorithms is presented. They can be largely classified depending on the use of speed sensors. As depicted in Figure 6, 
they are categorized into the main types, as direct power control (DPC) and indirect power control (IPC) [32,40] and other advanced methods using neural networks (NN) and Fuzzy logic controller (FLC) [41,42]. There are MPPT techniques such as tip speed ratio(TSR), power signal feedback (PSF), and optimal torque(OT) [43-45] under the IPC control scheme. In the IPC technique, the power is pre-calculated using the wind speed plots, which maximizes the mechanical power $P_{\text {wind }}$, while in the DPC scheme, the electrical power $\left(P_{\text {ele }}\right)$ is directly examined to operate the WT at the MPP. The DPC control scheme includes the MPPT algorithms such as perturb and observe ( $\mathrm{P} \& \mathrm{O})$ [46], incremental conductance (INC) [47], and optimal relation-based (ORB) [36,48]. An overview of several MPPT algorithms is presented in this section.

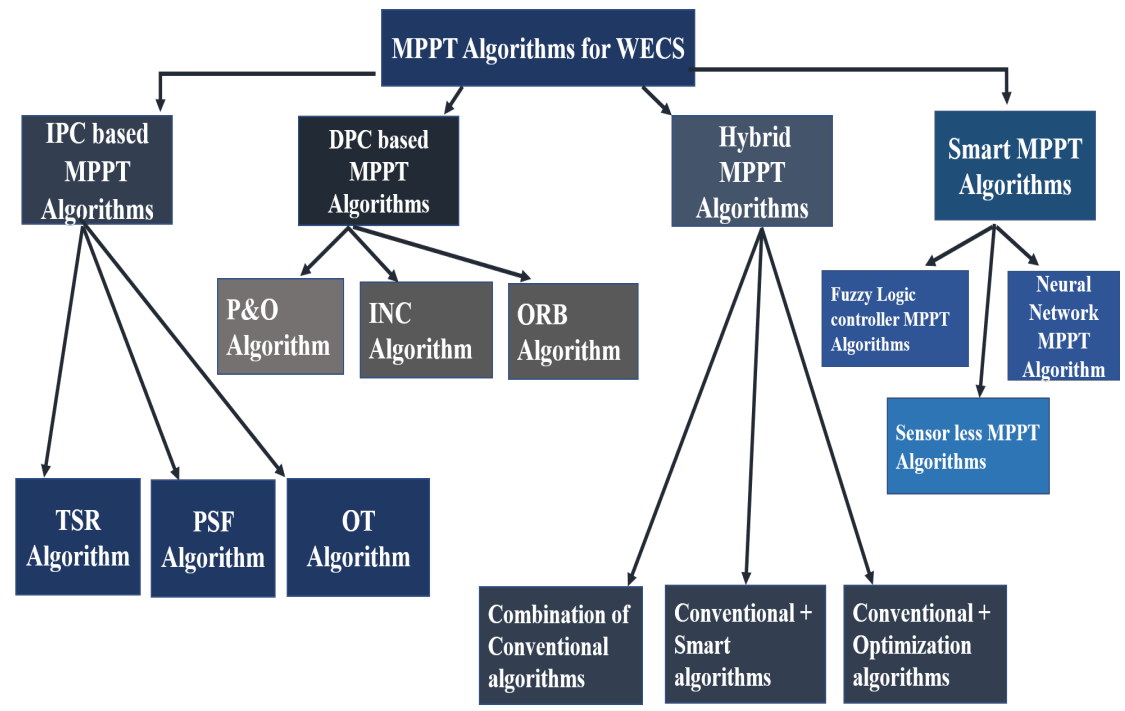

Figure 6. Classification of MPPT Algorithms for WECS.

\subsection{Conventional IPC Based MPPT Algorithms for WECS}

In this section, the IPC-based conventional MPPT algorithms for WECS are discussed.

\subsubsection{TSR MPPT Algorithm}

In this method, optimum TSR is obtained for the turbine to extract maximum power [49]. Figure 7 depicts this scheme. By estimating the speed of the rotor and the wind, an optimal reference speed of the rotor $\left(\omega_{r e f}\right)$ is generated. By considering the system parameters, the optimal power extraction is estimated in the TSR method [50-53]. The TSR MPPT algorithm has advantages such as rapid response and simplicity; hence, it is employed for regulation of the optimal rotor speed under changing environmental conditions [54-56]. Based on the acquired speed of the wind, there are two approaches. The first approach is based on the mechanical sensor employed and the second one on the estimation of the speed of wind [23]. In the first approach, the TSR algorithm based on the mechanical sensors makes use of multiple anemometers which surround the WT swept area with an accuracy of $-10 \%$ for measuring the speed of the wind [57]. The major drawback here is higher installation and initial cost and increased maintenance cost with lower efficiency and reduced reliability. In the second approach, wind speed estimation-based TSR algorithms were employed by researchers to overcome the drawbacks introduced due to the use of anemometers [58]. Wind speed estimation (WSE) algorithms provide higher accuracy in the calculated wind speed, although the accuracy decides the effectiveness in the tracking of energy as well as the harvesting. The efficient WSE algorithms based on the polynomial methods provide high accuracy, speed, and simplicity. These WSE algorithms are employed considering either the mathematical modeling of the WECS or considering the adaptive intelligent controllers [57,59-61]. 


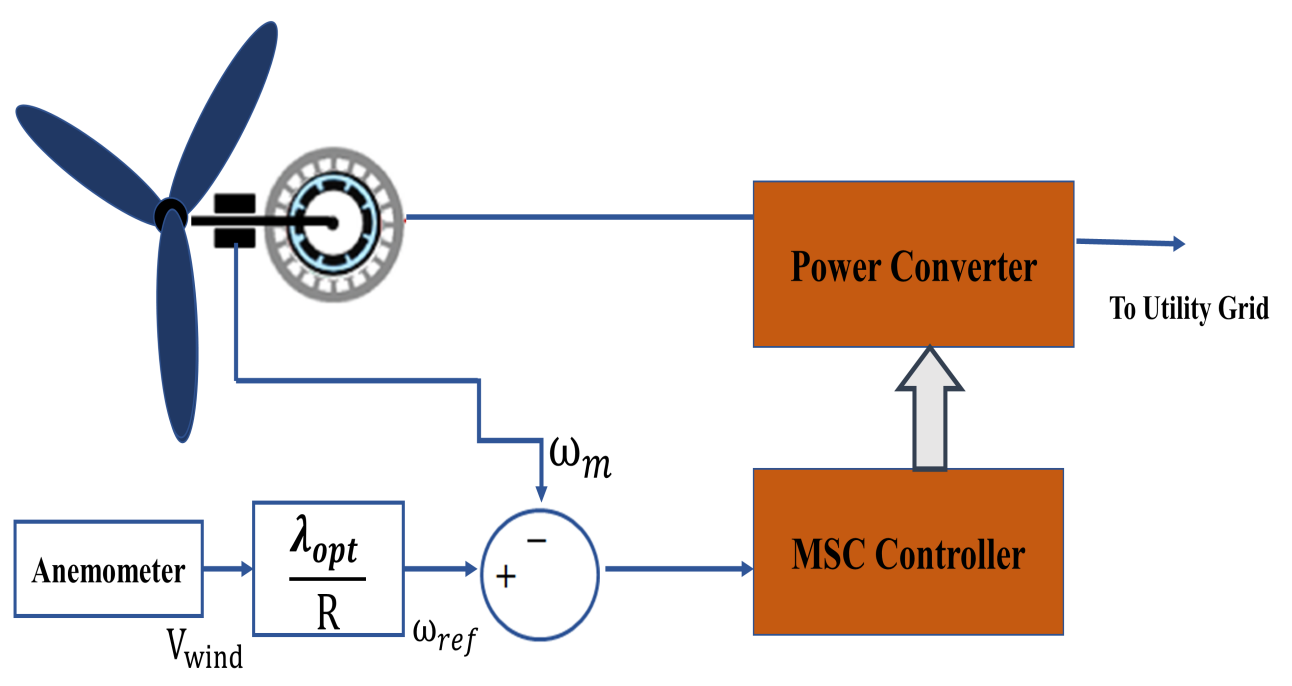

Figure 7. TSR MPPT algorithm.

\subsubsection{OT MPPT Algorithm}

The approach for the OT MPPT algorithm involves the regulation of generator torque by using the optimal torque curve for multiple wind speeds [52,55]. The scheme for this algorithm is as shown in Figure 8. The efficiency of the WT is dependant and defined by the optimum value of the constants of the turbine, which emphasizes the need for experimental validation [62-64]. The benefits of this technique are greater efficiency, simplicity, and high tracking speed, but it suffers from the issues of dependency on the climatic conditions and the requirement of knowledge of the characteristics of the WT $[65,66]$.

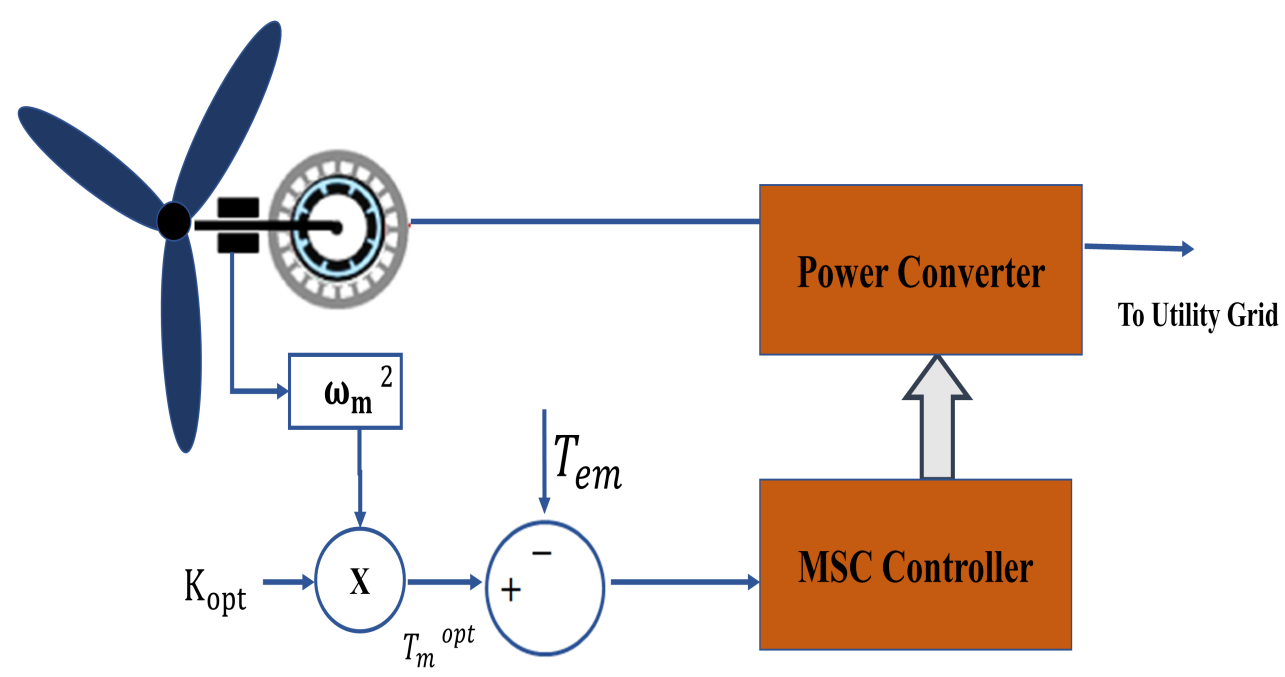

Figure 8. OT MPPT algorithm.

\subsubsection{PSF MPPT Algorithm}

In this method lookup tables for the optimal power $P_{m}^{o p t}$ are generated by experimental setup or by simulations for every WT [32]. The sensorless version of this algorithm measures the value of $P_{m}^{o p t}$ as the relation between the change occurring in the DC link and the present wind speed. The value of $\omega_{\text {ref }}$ is measured based on the optimal power curve and estimated electrical power [67]. The drawbacks of PSF and OT are almost similar while tracking the MPP for WT with high inertia at the lower speeds of the wind. Both the algorithms are low-cost and robust. Figure 9 shows the scheme for the PSF algorithm. 
A comparison of the IPC-based techniques is presented in Table 1. Table 2 gives a summary of references for the IPC based algorithms

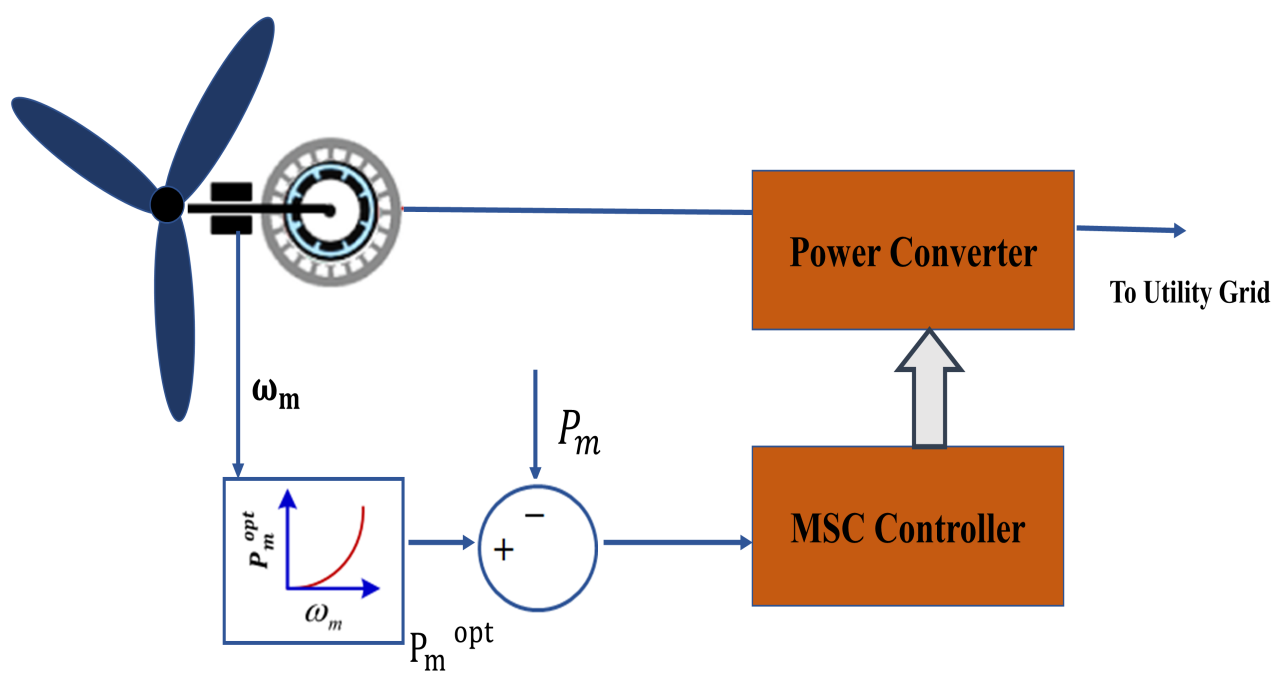

Figure 9. PSF MPPT algorithm.

Table 1. Comparison of IPC based MPPT Algorithms for WECS. Reused with permission from Ref. [32,34,36,68]. Copyright 2012, 2015, 2016 Elsevier.

\begin{tabular}{lccc}
\hline Features of the MPPT Algorithm & TSR & PSF & OT \\
\hline Efficiency & High efficiency & $\begin{array}{c}\text { Moderate } \\
\text { efficiency }\end{array}$ & High efficiency \\
\hline Complexity & Less & Less & Less \\
\hline Convergence speed & Higher & Higher & Higher \\
\hline Oscillations at MPP & No & No & No \\
\hline Prior knowledge & Not needed & Needed & Needed \\
\hline Memory requirement & No & Yes & No \\
\hline Sensors for wind speed measurement & Yes & Yes & No \\
\hline Parameter sensitivity & Yes & Yes & Yes \\
\hline $\begin{array}{l}\text { Cost } \\
\text { Online updating }\end{array}$ & Very high & Moderate & Moderate \\
\hline $\begin{array}{l}\text { Performance } \\
\text { speed }\end{array}$ & No & No & No \\
\hline
\end{tabular}


Table 2. Summary of references for IPC based MPPT Algorithms.

\begin{tabular}{|c|c|c|}
\hline Type of Algorithm & Reference & Remarks \\
\hline TSR & [52] & $\begin{array}{l}\text { TSR algorithm is compared with the OT algorithm and TSR is found to provide a } \\
\text { faster response to higher fluctuations in the wind speeds but suffers from the issue } \\
\text { of greater fluctuations in the output. }\end{array}$ \\
\hline TSR & [55] & $\begin{array}{l}\text { A technique is proposed for improvement in the efficiency of the TSR and OT } \\
\text { methods. }\end{array}$ \\
\hline TSR & [34] & $\begin{array}{l}\text { A review of different MPPT methods is presented. TSR algorithm requires speed } \\
\text { sensors and hence suffers from the issue of higher cost. }\end{array}$ \\
\hline OT & [55] & $\begin{array}{l}\text { A technique is proposed for improvement in the efficiency of the TSR and OT } \\
\text { methods. }\end{array}$ \\
\hline OT & [66] & Some of the drawbacks of OT algorithm are discussed. \\
\hline OT & [52] & $\begin{array}{l}\text { A comparison of the OT algorithm is conducted with the TSR algorithm and it } \\
\text { reveals that OT provides an improved response in terms of power smoothing and } \\
\text { power extraction. }\end{array}$ \\
\hline PSF & [32] & $\begin{array}{l}\text { A review of several algorithms is presented. The PSF algorithm provides higher } \\
\text { efficiency and faster response but has greater complexity. }\end{array}$ \\
\hline PSF & [34] & $\begin{array}{l}\text { A review of different MPPT methods is presented. PSF algorithm requires speed } \\
\text { sensors and knowledge of the parameters of the turbine and hence suffers from the } \\
\text { issue of higher complexity. }\end{array}$ \\
\hline
\end{tabular}

\subsection{Conventional DPC Based MPPT Algorithms for WECS}

Conventional DPC-based MPPT algorithms for WECS are discussed in this section. The DPC-based algorithms majorly include INC, P\&O and ORB MPPT algorithms.

\subsubsection{Conventional P\&O MPPT Algorithm}

The approach for the $\mathrm{P} \& \mathrm{O}$ algorithm involves the location of the MPP by employing the strategy of mathematical optimization. This method involves perturbation of the control variables such as either the dc-link voltage or the speed of the rotor, and their effect on the performance of WECS is observed. In the conventional P\&O (CPO) algorithm, the power obtained is amended along with the speed of the generator to obtain a zero slope for the P- $\omega$ curve. The most important features and advantages of this algorithm are that it does not need the sensors such as an anemometer, and also, there is no requirement of the knowledge of the WT parameters [36,69]. In the CPO algorithm, if the operating point lies towards the left of the MPP, then the controller moves it towards the right, and if it is on the left, then vice versa $[40,70]$. The optimal operating point is searched, and the maximum power is tracked in this method [71,72]. Figure 10 shows the flowchart for this scheme, and Figure 11 depicts the working concept of this algorithm. Due to its simplicity and ease of use, this technique is very popular. The important drawback of this algorithm is that it is challenging to decide upon an appropriate step size for perturbation since it affects the WT performance. Larger step sizes result in oscillation near the MPP. On the other hand, smaller step sizes will result in higher convergence time and slower response. Another issue is that of losing track of the MPP under varying speeds of the wind. Figure 12 depicts the issue of tracking the MPP under varying speeds of the wind. Figure 13 depicts this scheme. 


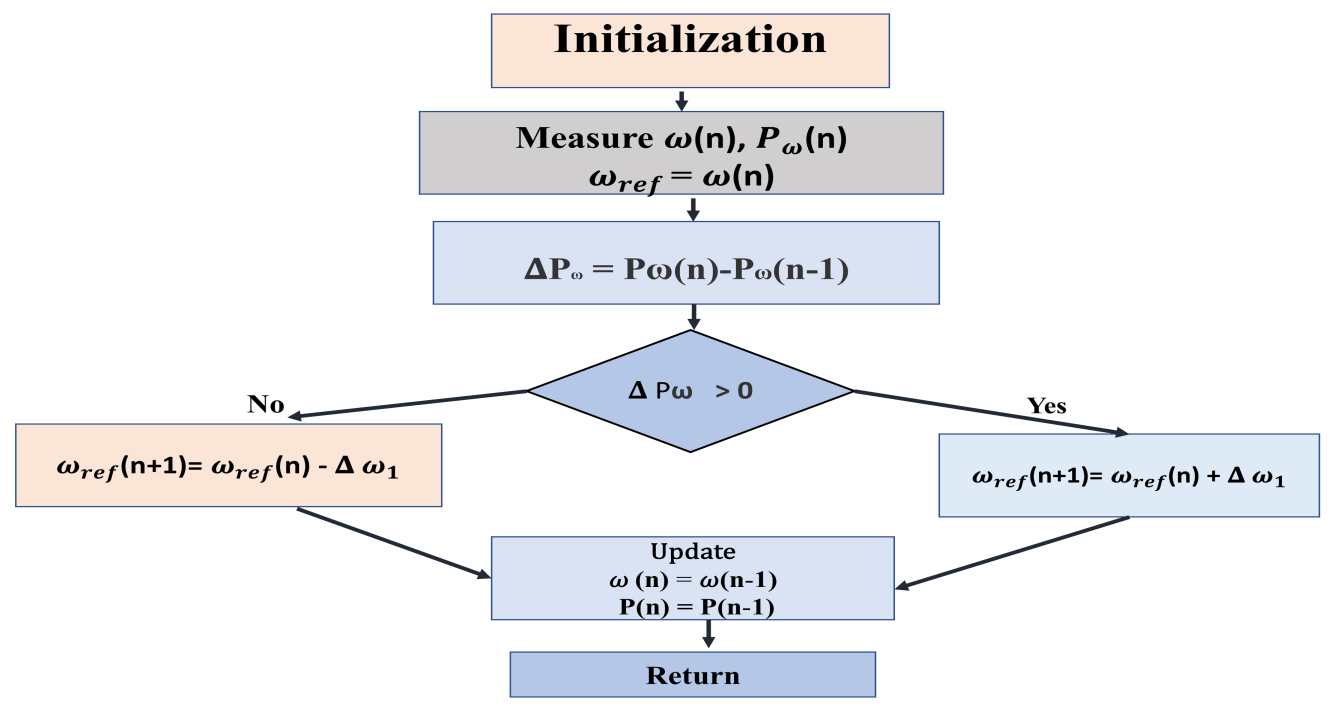

Figure 10. Flowchart of $\mathrm{CPO}$ algorithm.

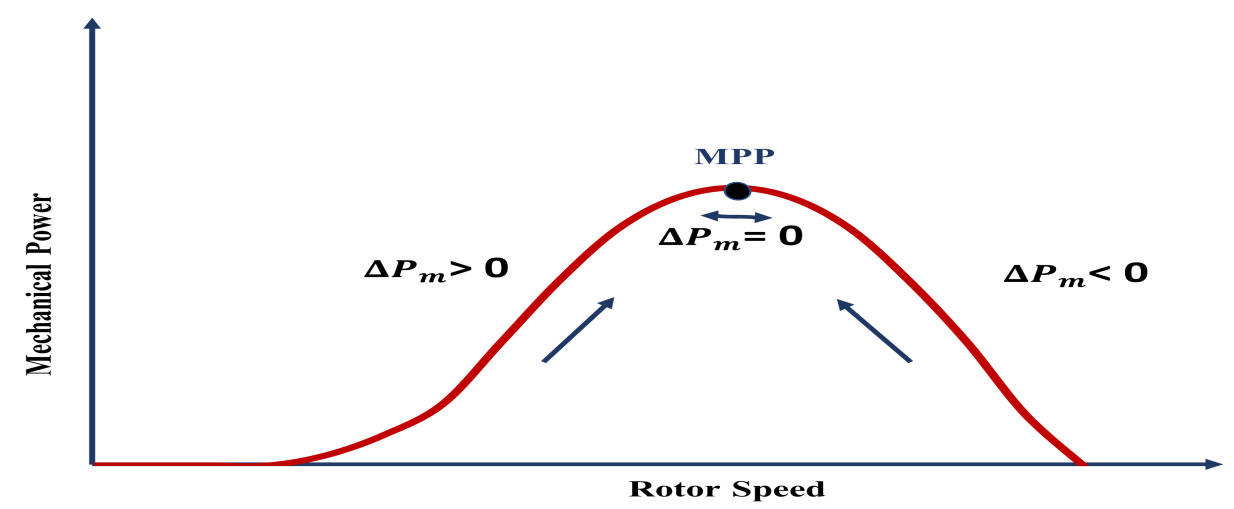

Figure 11. Concept of working of CPO MPPT algorithm. Reused with permission from ref. [3]. Copyright 2021 Elsevier.



Figure 12. Problem of tracking MPP under varying speeds of the wind. Reused with permission from ref. [3]. Copyright Elsevier 2021. 


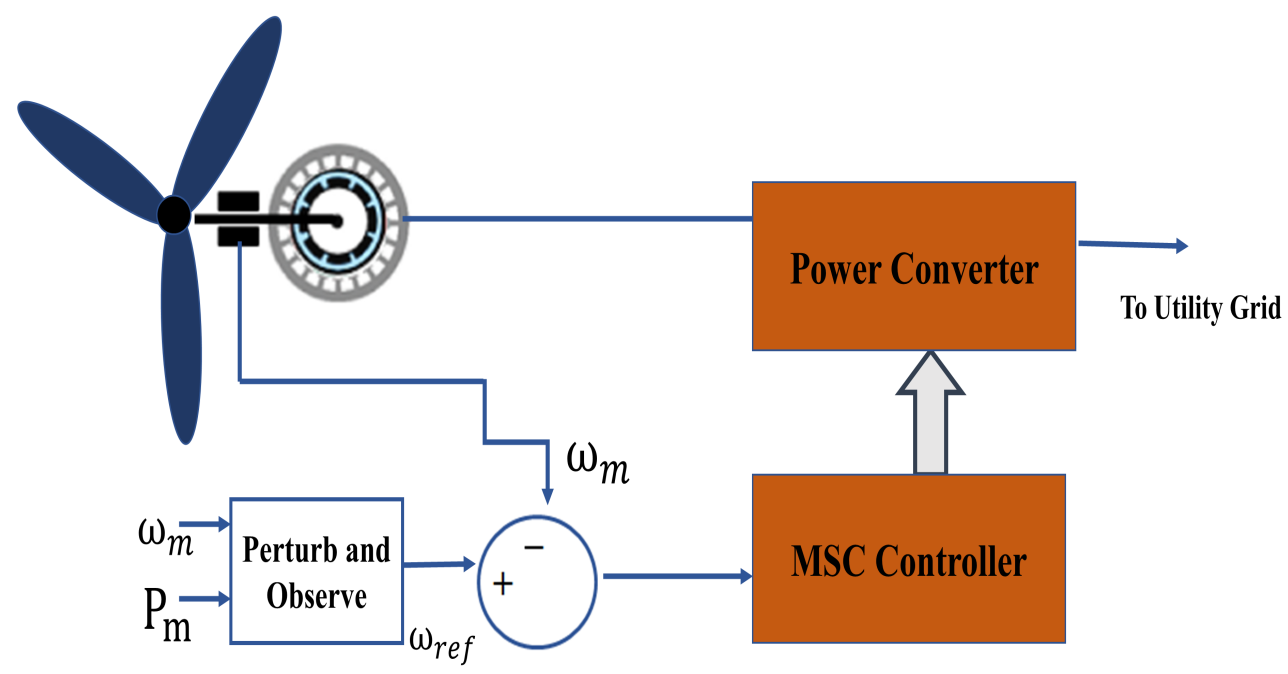

Figure 13. P\&O MPPT algorithm.

\subsubsection{Conventional INC MPPT Algorithm}

This method involves observation of the rectifier output power, which is used for tracking the MPP and deciding the perturbation direction. The need for sensors and the knowledge of the WT parameters is eliminated by using the INC algorithm, which results in the increased reliability and efficiency $[24,73]$. The changes in the dc-link voltage and current are used for determining the output power [74]. The control scheme is shown in Figure 14.

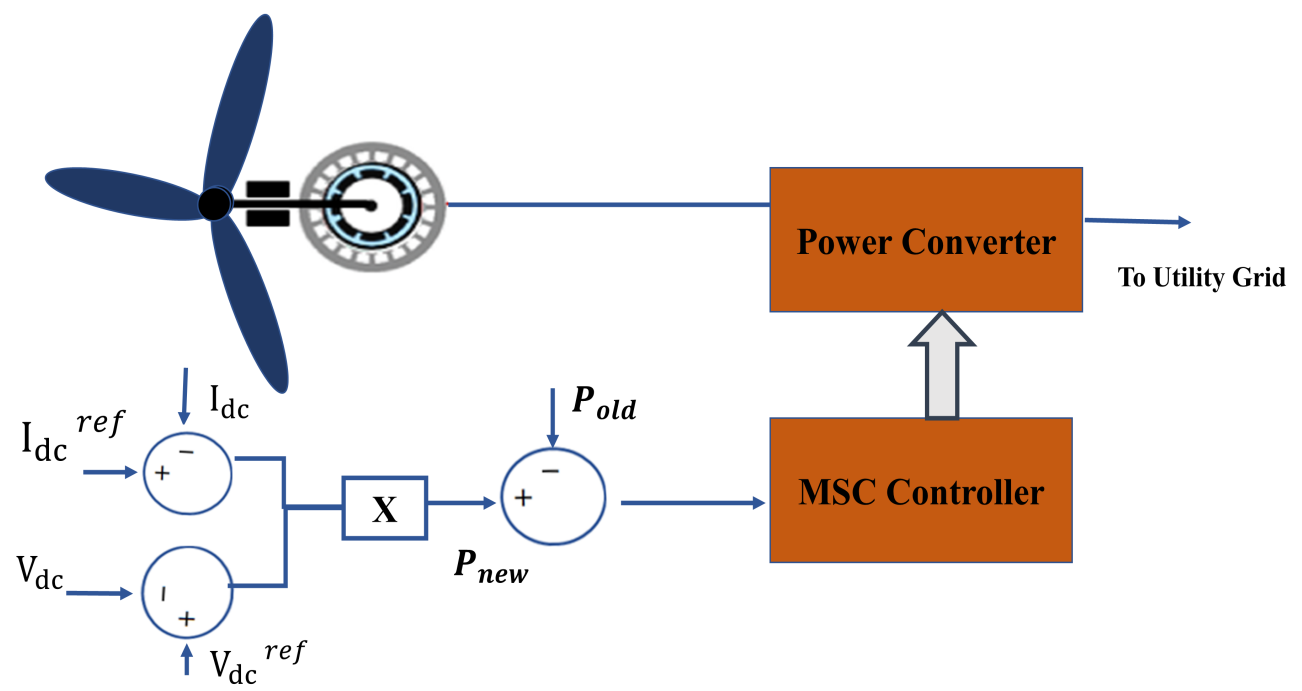

Figure 14. INC MPPT algorithm.

\subsubsection{Conventional ORB MPPT Algorithm}

This MPPT algorithm majorly relies on the predetermined relationship between the parameters of the WT [68,74-77]. The simplicity of this method is because only the values of DC power and voltage along with current serve as the inputs for this algorithm [12]. A few examples are optimum relation among the parameters such as power and speed of the rotor in $[78,79]$, electromagnetic torque and power in [80,81], rectified dc-link voltage versus power [41], and between dc-link current and voltage in [82]. When compared to the other algorithms, this method is found to provide faster response, and the operation is quite simple without the need for anemometers and hence is a preferred choice for commercial WECS $[18,83,84]$. However, the high memory requirement for the pre-obtained 
relation curves is a major disadvantage of this method [69,85]. Figure 15 portrays the control scheme of this algorithm. In Table 3, a comparison based on different characteristics of MPPT algorithms is made for DPC-based algorithms. A summary of references for the DPC based algorithms is given in Table 4.

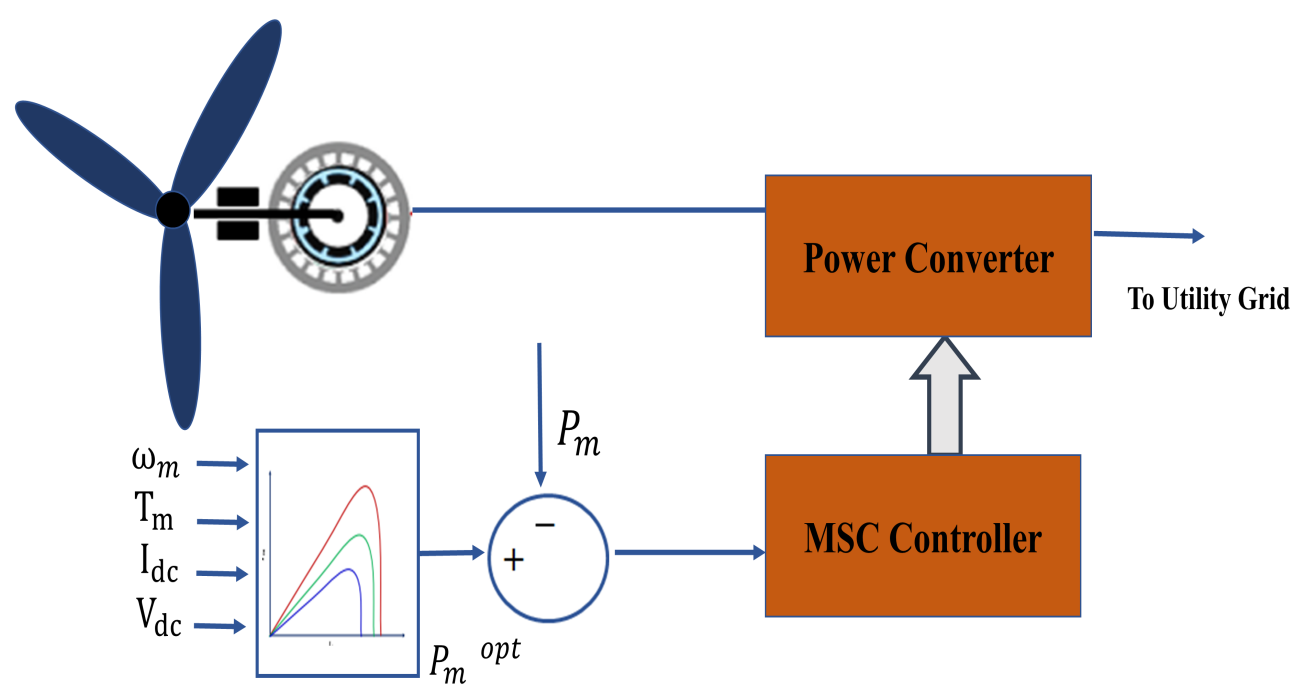

Figure 15. ORB MPPT algorithm.

Table 3. Comparison of DPC based MPPT Algorithms for WECS Reused with permission from ref. [32,34,36,68]. Copyright 2012, 2015, 2016 Elsevier.

\begin{tabular}{lccc}
\hline Features of the MPPT Algorithm & CPO & INC & ORB \\
\hline Efficiency & Low & Low & Moderate \\
\hline Complexity & Simple & Simple & Simple \\
\hline Convergence speed & Slow & Slow & Medium \\
\hline Oscillations at MPP & Yes & Yes & No \\
\hline Prior knowledge & Not needed & Not needed & Not needed \\
\hline Memory requirement & No & No & Yes \\
\hline Need of sensors for measuring wind speed & Not needed & Not needed & Not needed \\
\hline Parameter sensitivity & No & No & Yes \\
\hline Cost & Moderate & Moderate & High \\
\hline Online updating & Yes & Yes & No \\
\hline Performance under fluctuating wind speed & Moderately & Moderately fair & Moderately fair \\
\hline
\end{tabular}


Table 4. Summary of references for DPC based MPPT Algorithms.

\begin{tabular}{lrl}
\hline Type of Algorithm & Reference & Remarks \\
\hline CPO & $\begin{array}{l}\text { A review of several MPPT algorithms is presented and the basic working } \\
\text { concepts of these algorithms are described. The advantages of the CPO } \\
\text { algorithm such as ease of implementation and no requirement of the } \\
\text { sensors are listed. }\end{array}$ \\
\hline
\end{tabular}

$\mathrm{CPO}$

[72] tages of each of them are described. CPO being sensor less, is cheaper but suffers from the issue of lower efficiency for fluctuating wind speeds.

$\mathrm{CPO}$

[40] peakdetection technique. It eliminates the trade-off between the efficiency and speed.

ORB

[75] A sensorless technique to extract maximum power from WECS is presented.

ORB
[68] Several MPPT algorithms are discussed and reviewed.The drawbacks and advantages of ORB algorithm are also discussed.

The features, advantages and disadvantages of the CPO and the ORB [84] algorithms are discussed and a new algorithm which is a combination of the two is presented.

INC

[68]

Several MPPT algorithms are discussed and reviewed. The drawbacks and advantages of INC algorithm are also discussed.

INC

[74]

Two different boost converter topologies are used and compared by implementing the INC algorithm.

\subsection{Modified Conventional MPPT Algorithms for WECS}

The INC and CPO algorithms do not require sensors, and hence these are lower in cost, simple to implement, and the memory requirement for them is small. With these techniques, the calculation of the optimal power is conducted without any previous knowledge of the parameters and characteristics of the system. Besides these advantages, the CPO algorithm majorly suffers from the drawback of a trade-off between convergence and efficiency. As discussed above, the modified $\mathrm{P} \& \mathrm{O}$ algorithm (MPO) helps in eliminating these drawbacks. In addition, the modified INC algorithm is used to obtain a better system precision, performance, and convergence speed. Many variations have been brought about in the CPO algorithm due to its simplicity and ease of use. These variations and modifications have helped in overcoming the drawbacks of the $\mathrm{CPO}$ algorithms. MPO and the modified INC, OT, PSF algorithms are discussed in the section below.

\subsubsection{Modified Optimum Torque (OT) MPPT Algorithm}

The torque $T$ in conventional OT MPPT algorithm is given by Equation (4).

$$
T=(k \omega)^{2}
$$

A modification in this method is presented in $[33,81,86-88]$ in which the net torque is used to represent the acceleration or deceleration, which is given by Equation (5) where $G$ is the gain for adjusting the net torque, $\omega$ is the rotor speed and the mechanical torque $T_{m}$ that the WT captures.

$$
T=(k \omega)^{2}-G\left(T m-(k \omega)^{2}\right)
$$


The main objective in bringing about the modification is for faster tracking targeted at the large inertia of the turbine that creates hindrance in following the torque command when the wind speed is rapidly changing. This algorithm helps in better and faster tracking of the MPP.

\subsubsection{Modified PSF MPPT Algorithm}

The motivation behind using this modified form of PSF algorithm is to avoid the stalling of the generator, this is achieved by offsetting the power measured by a constant value $[41,89]$. The stator frequency derivative is feedback to increase the system sensitivity against the rapid wind speed changes. The major issue in this modified method is that unwanted overshoots are observed in the control variable, and achieving MPP becomes more cumbersome and difficult.

\subsubsection{Modified INC MPPT Algorithm}

A modification in the conventional INC algorithm, an adaptive INC algorithm, is presented in [90-94]. By changing the perturbation step size of the dc voltage, an enhancement is obtained in the dynamic performance of WECS as well as the speed of convergence, but the maximum amplitude of the step sizes is dependent on the parameters of the generator, and it is limited.

\subsubsection{Modified P\&O MPPT Algorithms}

The CPO MPPT algorithm is very simple, and low cost is a preferred choice for tracking the MPP. However, due to several drawbacks, as discussed in the earlier section, the replacement of the CPO is gaining popularity among researchers. The modifications in CPO involve changes in the strategy of tracking and hence called modified P\&O algorithms(MPO) which made use of the variable and adaptive step size [76,95]. Depending on the type of step size used for perturbation of the control variables, the classification of step sizes is as stated below,

- $\quad$ Fixed step sizes: A fixed amplitude of the step size is employed to perturb the control variable while carrying out the tracking procedure.

- Variable step sizes: Step sizes of varying amplitudes are employed, with a unique step size for each region.

- $\quad$ Adaptive step sizes: The step size employed for perturbation is finalized depending on the variation in the general objective function at each operating point.

- Hybrid step sizes: A combination of two different generated step sizes while MPP tracking is employed. Figure $16 a-d$ portrays the P\&O algorithm-based categories of step sizes that are generated while carrying out the tracking process. Table 5 summarizes the P\&O method-based generated step sizes, and Table 6 summarizes the references for modified MPPT algorithms. Finally, Figure 17 shows the classification of $\mathrm{P} \& \mathrm{O}$ algorithms for WECS.

The MPO algorithms can also be grouped based on the generic objective function, optimization techniques, power curve division, and hybrid techniques. The approach of power curve division facilitates managing the step size in each of the regions individually. The way the MPO will work with adaptive, hybrid, or variable step sizes is influenced by the number of regions of operation and the way the power curve is divided. The synthesized curve, relations, or ratios can be used to decide the approach for power curve division. As discussed in [96-98], the power speed curve can be divided into multiple regions, and the synthesized curve is implemented, and anemometers are employed to produce four operating regions, with each of them having a unique step size. The issue with this method is that owing to fewer operating regions, there is a noticeable transient overshoot. Another issue is the need for sensors. The complexity involved in the synthesized curve is reduced by using the synthesized ratio that involves measuring either the changes in the output power, speed of the rotor, or both. In [23,99], the estimation of optimal power is conducted for finding the synthesized ratio. In the synthesized relations strategy, general 
relations are stated by the observation of the control variables. The related control variables are current, voltage, output power, or the perturbation step size. They are used for splitting the power curve into multiple regions of operation. The rotor speed is regulated with the help of the alterations in the power within the specified limits in [100]. In [101,102], the definite conditions are used as a replacement for the lookup table. Intermediate variables with dual control mode are presented in $[103,104]$. The strategy of dividing the power curve suffers from limitations such as the complexity of the system and the requirement of accurate tuning of several parameters. Hence, other methods employing the generic objective function are used for enhancing the $\mathrm{CPO}$ algorithm performance.

Many researchers have used optimization techniques in the domain of PV applications. The domain of WECS also has made use of several optimization techniques. The process of CPO algorithm optimization can be carried out by using the Wilcoxon radial basis function network as discussed in $[105,106]$. The strategy of optimization of the line of search to achieve optimal conditions for operation is presented in [107]. As presented in [108], proportional integral derivative (PID) controllers are optimized for employing with the $\mathrm{P} \& \mathrm{O}$ algorithms.

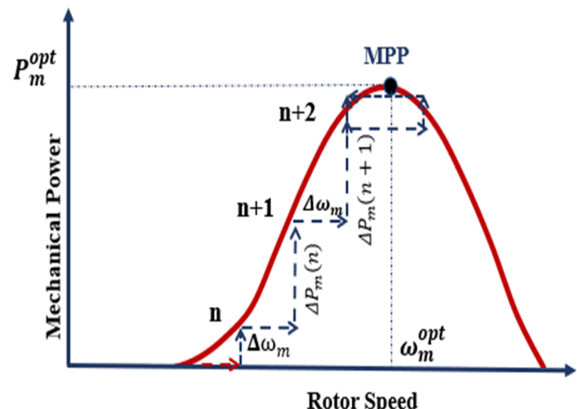

(a) Fixed Step sizes

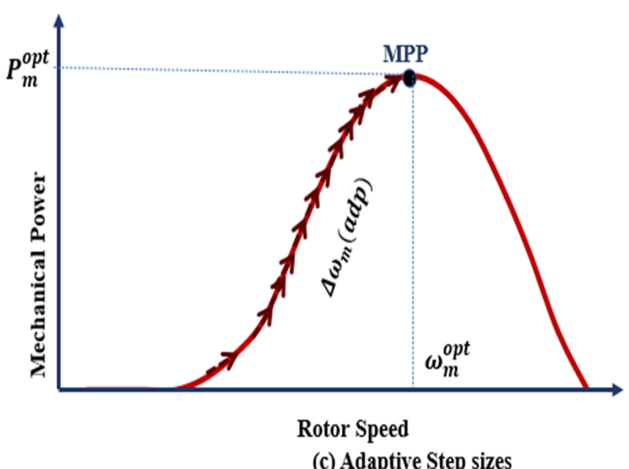

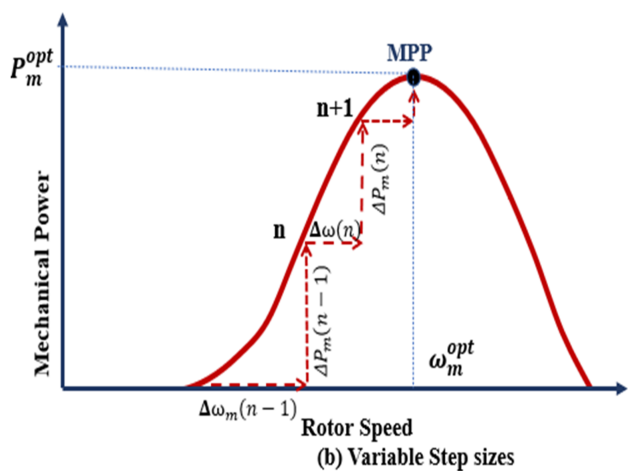

(b) Variable Step sizes



Figure 16. $\mathrm{P} \& \mathrm{O}$ algorithm-based types of step sizes generated. Reused with permission from Ref. [3]. Copyright 2021 Elsevier. 


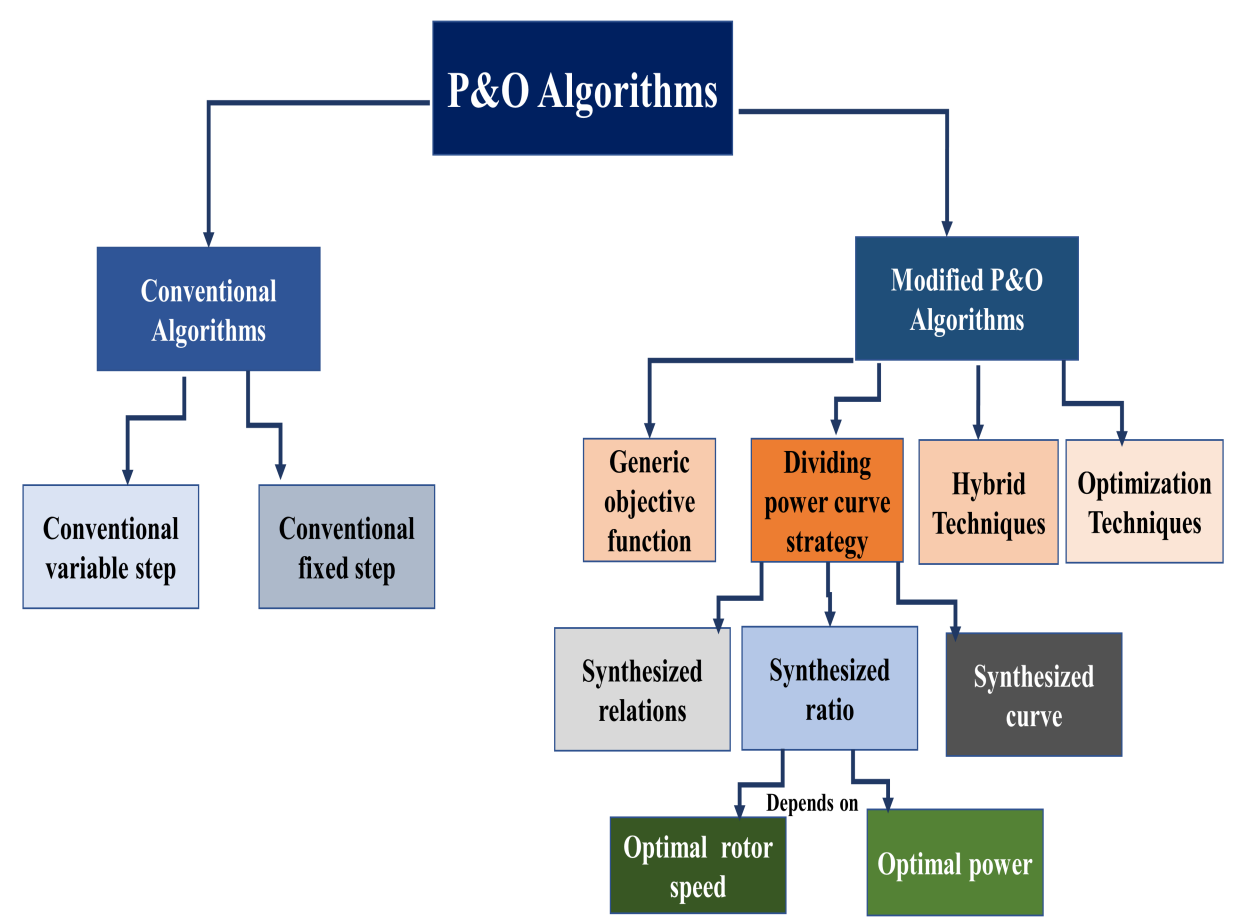

Figure 17. Classification of $\mathrm{P} \& \mathrm{O}$ algorithm. Reused with permission from Ref. [3]. Copyright 2021 Elsevier.

Table 5. Comparison of $\mathrm{P} \& \mathrm{O}$ algorithm based types of step sizes generated.

\begin{tabular}{cll}
\hline Generated Step Size Type & Reference & Remarks \\
\hline Fixed step size & {$[42,109-111]$} & $\begin{array}{l}\text { Challenging to decide the step size used for perturbation, } \\
\text { and significant oscillation of the MPP is observed near } \\
\text { the MPP. }\end{array}$ \\
\hline Variable step size & {$[23,24,89,112,113]$} & $\begin{array}{l}\text { The oscillations around the MPP and higher tracking } \\
\text { time are well addressed, although the step size procure- } \\
\text { ment strategy results in higher complexity. }\end{array}$ \\
\hline Adaptive step size & $\begin{array}{l}\text { Depending on the definite objective function, accurate } \\
\text { larification of the relation among the control variables, } \\
\text { and wind speed, the step sizes are varied. The objective } \\
\text { function can be dependent on multiple constants. Accu- } \\
\text { rate tuning of these constants needs to be conducted by } \\
\text { the process of complex competition analysis. }\end{array}$ \\
\hline Hybrid step size & $\begin{array}{l}\text { Step sizes of different types are generated. Their opera- } \\
\text { tion order and their activation need accurate designing } \\
\text { and add to the complexity. }\end{array}$ \\
\hline
\end{tabular}


Table 6. Summary of references for the modified MPPT algorithms.

\begin{tabular}{|c|c|c|}
\hline Type of Algorithm & Reference & Remarks \\
\hline Modified OT & [81] & A sensor less modification in the OT algorithm is presented. \\
\hline Modified OT & [33] & $\begin{array}{l}\text { A review of different MPPT algorithms is presented and the modification in } \\
\text { the OT algorithm is also mentioned. }\end{array}$ \\
\hline Modified PSF & [33] & $\begin{array}{l}\text { A review of different MPPT algorithms is presented and the modification in } \\
\text { the PSF algorithm is also mentioned. }\end{array}$ \\
\hline Modified PSF & [89] & $\begin{array}{l}\text { An Intelligent algorithm for extracting maximum power from WECS is pre- } \\
\text { sented. }\end{array}$ \\
\hline Modified INC & [92] & An ANN based modified INC algorithm for photovoltaic systems is presented. \\
\hline Modified PO & [93] & A modified version of INC algorithm is presented for a PMSG micro-WT. \\
\hline Modified PO & [3] & A review of C PO and MPO MPPT algorithms is presented. \\
\hline Modified PO & [23] & $\begin{array}{l}\text { A modular sector MPO algorithm that eliminates the drawbacks of the CPO } \\
\text { algorithm is presented. }\end{array}$ \\
\hline Modified PO & [24] & $\begin{array}{l}\text { A MPO algorithm for a variable speed WECS is investigated for a five-phase } \\
\text { large scale system. }\end{array}$ \\
\hline Modified PO & [38] & $\begin{array}{l}\text { An MPO algorithm that employs variable step sizes and makes use of model } \\
\text { reference adaptive control, which helps eliminate the issues of CPO, is pre- } \\
\text { sented. }\end{array}$ \\
\hline
\end{tabular}

\subsection{Smart MPPT Algorithms}

Intelligent controllers such as neural networks (NN) and fuzzy logic controller (FLC), and several soft computing-based algorithms are available in the literature $[117,118]$. Several soft computing algorithms have proven to be an attractive option for WECS based applications since no mathematical parameters of the WECS are needed $[55,119]$ although the accuracy of the optimal response of the control variables is not very precise. Numerous adaptive algorithms are available in the literature which does not make use of mechanical sensors and are used for treating the uncertainty of the system during optimal conditions as presented in [120-122]. A brief overview of the FLC, NN, sensorless, and multi-variable P\&O MPPT algorithms is presented in this section. There are MPPT algorithms based on optimization algorithms that are proposed in the literature, such as Cuckoo Search (CS), Genetic Algorithm, Particle Swarm Optimization (PSO), Teaching Learning Based Optimization (TLBO), Grey Wolf Optimization, are employed with the conventional ones to eliminate the shortcomings of the conventional MPPT algorithms [28,96,123-126]. In a solar and wind hybrid system, the ant colony optimization(ACO) provides a faster convergence as compared to the PSO algorithm [127]. A comparison of the smart MPPT algorithms for WECS is presented in Table 7. 
Table 7. Comparison of Smart MPPT Algorithms for WECS. Reused with permission from ref. [34,35,68,128,129]. Copyright 2011, 2015, 2016 Elsevier.

\begin{tabular}{lccccc}
\hline Features of the MPPT Algorithm & FLC & NN & $\begin{array}{c}\text { Sensor } \\
\text { Less }\end{array}$ & MVPO & Other \\
\hline Efficiency & Higher & Higher & Moderate & Moderate & Depends \\
\hline Complexity & Higher & Higher & Higher & Higher & $\begin{array}{c}\text { Moderately } \\
\text { complex }\end{array}$ \\
\hline Speed of convergence & Medium & Medium & Medium & Slow & Medium \\
\hline Oscillations at MPP & $\begin{array}{c}\text { Do not } \\
\text { occur }\end{array}$ & Do not occur & Depends & Occur & Depends \\
\hline Prior knowledge & Needed & Needed & Not needed & Not needed & Depends \\
\hline Memory & Required & Required & Required & $\begin{array}{c}\text { Not } \\
\text { Required }\end{array}$ & Depends \\
\hline $\begin{array}{l}\text { Need of sensors for wind speed measure- } \\
\text { ment }\end{array}$ & Depends & Depends & Not needed & Not needed & Depends \\
\hline Parameter sensitivity & Depends & Depends & Not found & Not found & Depends \\
\hline Cost & Higher & Higher & Lower & Lower & Medium \\
\hline Online updating & Required & Required & Depends & Required & Depends \\
\hline Performance under fluctuating wind speed & Higher & Higher & Higher & Moderate & Moderate \\
\hline
\end{tabular}

\subsubsection{Fuzzy Logic Controller Based MPPT Algorithm}

The issue of oscillations around the MPP is addressed by employing FLCs for the MPPT algorithm. This method is characterized by the fact that variables of the controller can be rapidly changed, corresponding to the changes that occur in the dynamics of the system. Therefore, there is no need for the mathematical modeling of WECS. The overall system performance of this type of method is good even under varying climatic conditions. Although it is possible only when proper rules are designed by the user with adequate knowledge of the system for selection of the appropriate rule base, membership functions, and high requirement of memory is also a major issue [32,130-133]. Different FLC based MPPT algorithms are presented in $[107,108,117-119,134]$. Figure 18 depicts the FLC scheme for WECS. 


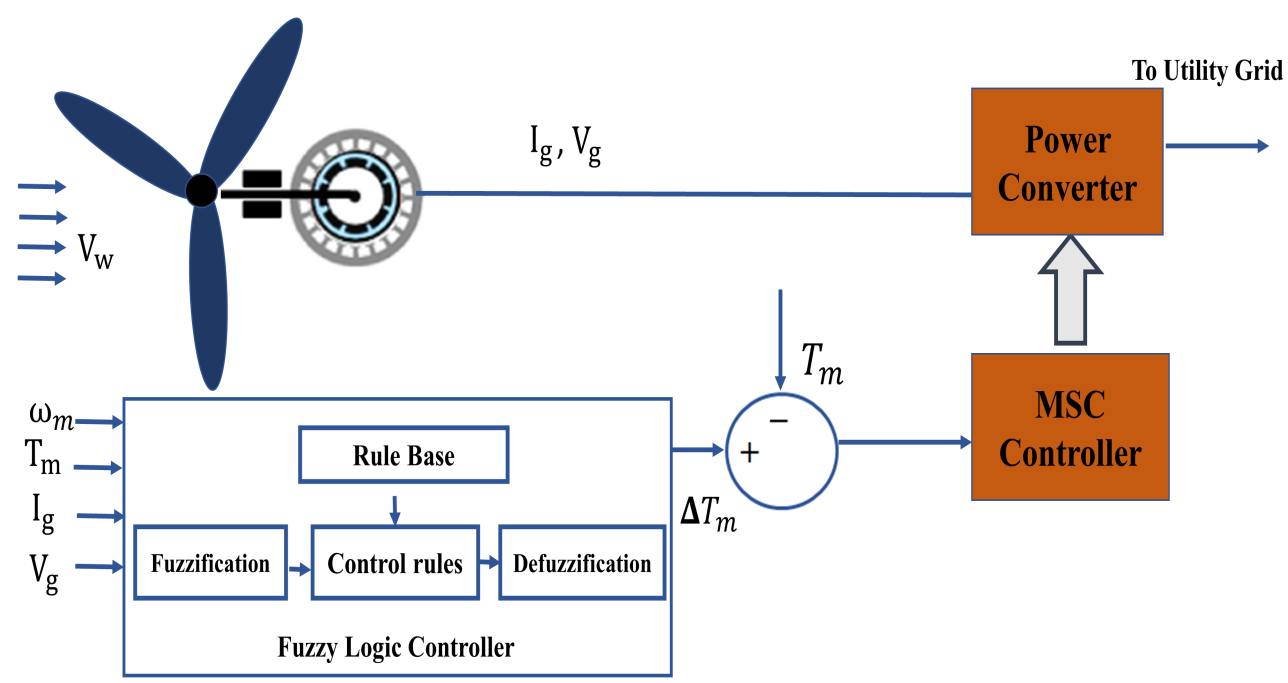

Figure 18. Fuzzy logic based MPPT algorithm for WECS.

\subsubsection{Neural Network Based MPPT Algorithm}

There are three layers in the neural network architecture, that are the input, hidden, and output layers. The user decides how many nodes he will use and can vary from user to user [135-137]. Several variables are used as the input variables such as the terminal voltage, wind speed, output torque, etc. The output provided serves as a reference variable such as the reference power or the speed of the rotor to drive the power electronic circuitry. The weights given to the layers decide how the operating point will coincide with the peak point. The training is given to the system for the particular input-output pattern [138]. The training results in the reduction of the response time which facilitates the quick achievement of the steady state even under varying wind velocities. This method provides an improvement in the trade-off between the response time and the output power.

\subsubsection{Smart Sensorless MPPT Algorithms}

The sensorless approach helps in the elimination of the mechanical sensors and the need for prior knowledge of the characteristics of the WT [113,139-141]]. Researchers have proposed sensorless MPPT algorithms for accurate measurement of wind speed as discussed in [142-144]. FLC-based and NN-based MPPT algorithms in which the prior knowledge of the WT is not required are discussed in [110-112].

\subsubsection{Multi-Variable Perturb and Observe MPPT Algorithms}

This algorithm aims at producing maximum power by employing a minimum number of sensors control units in a wind farm. MVPO algorithm yields higher generated power with lesser components for a wind farm $[76,145,146]$. The adoption of the MPO algorithm has facilitated optimization of currents of all the generators by perturbation of current of the individual generators until there is increased power in the wind farm. This procedure is iteratively performed to cover every generator in the wind farm [147].

\subsection{Hybrid MPPT Algorithms}

As described in the previous sections, each of the conventional algorithms has its advantages and disadvantages. Two or more algorithms are merged or clubbed together to form a hybrid algorithm, to make the best use of the advantages of two different algorithms and get rid of their disadvantages, and thereby enhance the performance of the WECS $[17,119,148]$. Several combinations of the conventional algorithms are available in the literature, and some are described below in this section. Table 8 summarizes references for the smart and hybrid MPPT algorithms, and Table 9 presents a comparison of the hybrid MPPT algorithms. Table 10 gives a list of symbols. 
Table 8. Summary of references for Smart and Hybrid MPPT algorithms.

\begin{tabular}{|c|c|c|}
\hline Type of Algorithm & Reference & Remarks \\
\hline Smart & [132] & $\begin{array}{l}\text { MPPT algorithm based on FLC that makes use of the master-slave FLC training } \\
\text { mode is presented. }\end{array}$ \\
\hline Smart & [130] & An intelligent MPPT algorithm based on ANN is presented. \\
\hline Smart & [37] & $\begin{array}{l}\text { A review of MPPT algorithms is presented and the MVPO algorithm is dis- } \\
\text { cussed. }\end{array}$ \\
\hline PO based Hybrid & [149] & $\begin{array}{l}\text { A combination of FLC with CPO is employed that provides improved tracking } \\
\text { of the MPP. }\end{array}$ \\
\hline PO based Hybrid & [150] & $\begin{array}{l}\text { The self-tuning P\&O is combined with the ORB algorithm and this combination } \\
\text { provides better MPP tracking. }\end{array}$ \\
\hline PO based Hybrid & [151] & The combination of MPO and PSF is employed to improve the efficiency. \\
\hline PO based Hybrid & {$[152]$} & A combination of ANN and PSF is employed which results in better accuracy. \\
\hline $\begin{array}{l}\text { Optimization based } \\
\text { Hybrid }\end{array}$ & [153] & $\begin{array}{l}\text { The combination of ORB and (PSO) is employed to form the hybrid MPPT } \\
\text { algorithm. PSO is used in the first phase to search the optimum coefficient and } \\
\text { in the second phase, ORB is used. This method yields higher efficiency. }\end{array}$ \\
\hline
\end{tabular}

Table 9. Comparison of Hybrid MPPT Algorithms for WECS. Reused with permission from Refs. [32,34,36,68,113,128]. Copyright 2011, 2012, 2015, 2016 Elsevier.

\begin{tabular}{lc}
\hline Features of the MPPT Algorithm & Hybrid \\
\hline Efficiency & Very high \\
\hline Complexity & Medium \\
\hline Convergence speed & Fast \\
\hline Oscillations at MPP & Depends \\
\hline Prior knowledge & Not needed \\
\hline Memory requirement & No \\
\hline Wind speed sensor & Depends \\
\hline Parameter sensitivity & No \\
\hline Cost & Moderate \\
\hline Online updating & Depends \\
\hline Performance under fluctuating wind speed & Good \\
\hline
\end{tabular}


Table 10. List of symbols.

\begin{tabular}{ll}
\hline$\beta$ & Pitch angle \\
\hline$C_{p}$ & Power coefficient \\
\hline$P_{m}$ & Mechanical power (watts) \\
\hline$\lambda$ & Tip speed ratio \\
\hline$\lambda_{\text {opt }}$ & Optimum tip speed ratio \\
\hline$V_{\text {cutin }}$ & Cut-in wind speed (m/s) \\
\hline$V_{\text {cutout }}$ & Cut-out wind speed (m/s) \\
\hline$V_{\text {rated }}$ & Rated wind speed (m/s) \\
\hline$C_{\text {popt }}$ & Optimal power coefficient \\
\hline$P_{\text {opt }}$ & Optimal power (watts) \\
\hline$\omega_{m}$ & Mechanical angular speed of the turbine (rad/s) \\
\hline$V_{d c}$ & DC voltage (volts) \\
\hline$P_{m}^{\text {opt }}$ & Optimal mechanical power (watts) \\
\hline$\omega$ & Rotor angular speed (rad/s) \\
\hline$\omega_{\text {ref }}, \omega_{\text {opt }}$ & Reference rotor speed (rad/s) \\
\hline$T_{m}$ & Mechanical torque ( N.m.) \\
\hline$T_{\text {em }}$ & Electromagnetic torque ( N.m.) \\
\hline$T_{m}^{\text {opt }}$ & Optimum mechanical torque (N.m.) \\
\hline$V_{\text {wind }}$ & Wind speed (m/s) \\
\hline & \\
\hline & \\
\hline
\end{tabular}

\subsubsection{P\&O Based Hybrid MPPT Algorithms}

The simplicity and ease of use of CPO have been exploited for its use in hybrid algorithms by many researchers. The problems that occur in the CPO MPPT algorithm of oscillations around the MPP, the trade-off between speed and efficiency, and change in the wrong direction under a rapid change in the wind speed are overcome by combining it with other algorithms. OTC is combined with the HCS or conventional P\&O. This combination helps in overcoming two issues. First is the issue of the trade-off between speed and efficiency, and the second is the wrong direction change under high-speed fluctuations of the wind [35]. Fuzzy logic control (FLC) is clubbed together with the CPO MPPT algorithm [149]. Combining these two improves MPP tracking. Self-tuning P\&O algorithm merged with the ORB algorithm is presented in [150] which works in two modes and provides better MPP tracking. Other algorithms that are merged with $\mathrm{CPO}$ are OT, INC, TSR, and PSF for overcoming the related shortcomings of CPO, specifically the issue of incorrect directionality due to fluctuations in the speed of the wind, are presented in $[40,69,90,154,155]$. Modified P\&O merged with PSF is presented in [151] where MPP is first tracked using MPO and employs PSF after that. MPPT based on ANN employing the $\mathrm{P} \& \mathrm{O}$ rules is discussed in [152], and the important benefits of using this technique are that it eliminates the need for the information about the values of $\lambda$ and $C_{p}$ and also provides better accuracy. Figure 19 portrays different P\&O-based hybrid MPPT algorithms. 


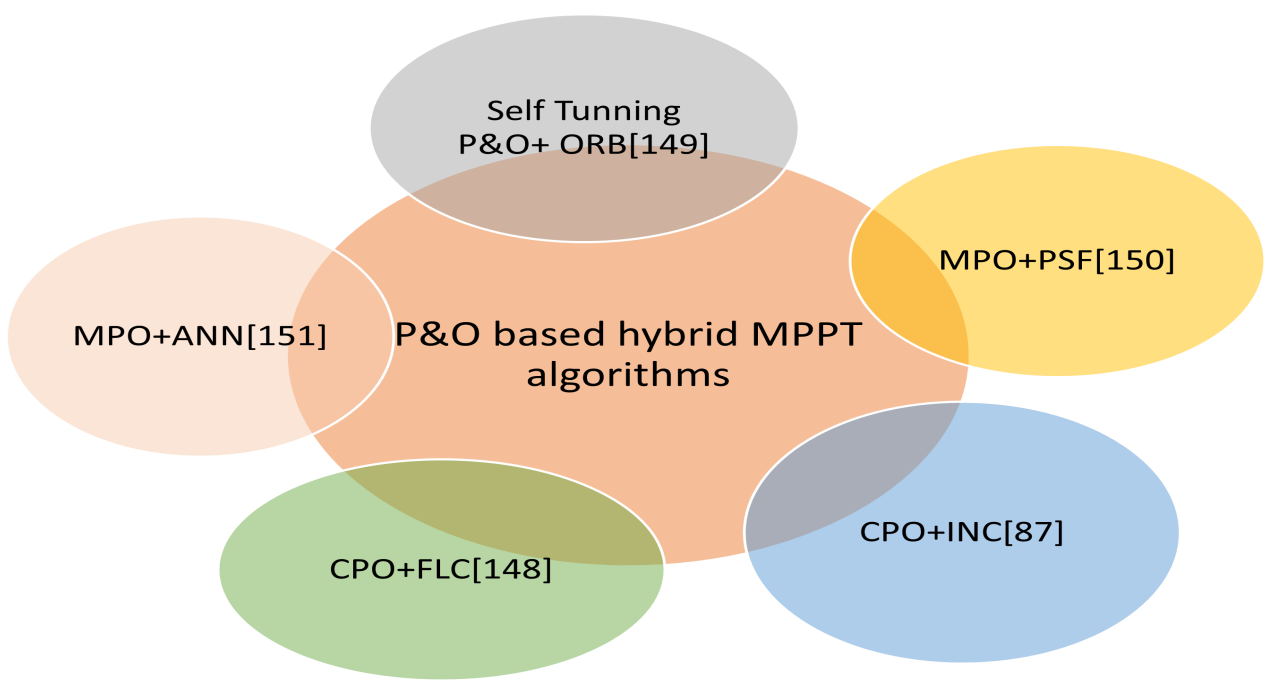

Figure 19. $\mathrm{P} \& \mathrm{O}$ based hybrid MPPT algorithms.

\subsubsection{Optimization Algorithms Based Hybrid MPPT Algorithms}

The combination of conventional MPPT algorithms and optimization algorithms are proposed, such as particle swarm optimization (PSO) employed with the conventional ones to eliminate the shortcomings of the conventional MPPT algorithms. The combination of ORB and particle swarm optimization (PSO) is used in [153]. In the first phase, PSO is employed for searching the optimum coefficient, and in the second phase, ORB MPPT is used. This technique increases efficiency, and no sensors and knowledge of the parameters are required for this hybrid method. MPPT algorithm based on the combination of PSF, soft stalling, and PSO controllers helps improve the efficiency over the entire speed range of the WT [156].

\section{Discussion}

The main objective behind the use of the MPPT algorithm is tracking and capturing the maximum power from the WECS. It is a tough task to select an appropriate algorithm. The comparative study reveals that the conventional IPC-based algorithms are faster and simpler to implement, but they capture mechanical power rather than electrical power. The DPC-based conventional algorithms do not require sensors, are low cost and are easy to implement. However, these algorithms do not provide satisfactory performance when the fluctuations are high in the speed of the wind. The CPO algorithm is immensely popular as it has several advantages of being simple, low cost, and easy to implement. However, it suffers from oscillations around the MPP and poor performance at higher fluctuating wind speeds.

The use of MPO has eliminated the drawbacks of this method. Several modifications are evident in the literature based on the step size employed for MPO algorithms. It is challenging for the methods with fixed step size to decide upon the step size for perturbation as a significant oscillation of the MPP is observed. By employing the variable step sizes, the oscillations around the MPP and higher tracking time issues can be very well addressed, although the step size procurement strategy results in higher complexity. In the case of hybrid step sizes, step sizes of different types are generated. However, their operation order and their activation need accurate designing and add to the complexity. It is evident from the literature that the demerits of an individual algorithm can be eliminated by either using the modified form or by employing hybrid techniques. The smart algorithms are efficient but suffer from issues such as high complexity, higher cost and may require speed sensors. The hybrid algorithms are promising as they are highly efficient, although they may need sensors depending on the combinations employed. The power coefficient is dependent on the air density. There can be a considerable variation in the air density over 
various seasons and different climatic conditions. The value considered for the air density is fixed while training the system, and as a result, optimum tracking of the maximum power in all the seasons and different environmental conditions may not be achieved. Some smart and hybrid MPPT algorithms are not generic and require sensors for wind velocity measurement while training. These are the issues that still need to be addressed.

\section{Trends and Future Scope}

This review reveals that the MPO has gained immense popularity among researchers, and this has given rise to several developments for providing reliable and improved MPP tracking techniques. The trend of using modified versions of $\mathrm{P} \& \mathrm{O}$ algorithms is also observed in the literature for the hybrid methods. The future trends will majorly be dealing with the extensive usage of optimization techniques and hybrid techniques employed for MPO-based algorithms. Optimizing generated step sizes by employing the simpler MPO methods can be seen as a promising research area.

\section{Conclusions}

MPPT algorithms have proven to be a key factor that aid in capturing and extracting maximum power from WECS. A large variety of algorithms are available in the literature. There is a need to devise a technique that can be very useful for the designers in making an appropriate choice of algorithm among the several available, for a given setup and thereby enhance the system performance to maximize the output produced.

In this paper, the MPPT algorithms of the past and present for WECS have been reviewed and compared. A comparison of the conventional algorithms based on IPC and DPC is conducted, followed by the hybrid and the smart algorithms. From the comparative study, the hybrid algorithms are found to be highly efficient. The hybrid MPPT algorithms can bring into use the advantages of the conventional methods and eliminate their drawbacks. The MPO algorithm has evolved in the recent years. The trend of preferring the $\mathrm{P} \& \mathrm{O}$ technique to enhance the extraction of power from WECS is evident from the literature due to its different features. Several modifications are evident in the literature based on the step size employed for MPO algorithms. Depending on the step size produced and the tracking approach used, the MPO algorithms are classified. The approach of generated step size includes fixed, adaptive, variable, and hybrid. The classification includes the main groups based on hybrid methods, optimization techniques, objective function, and power curve division. It is challenging for the methods with fixed step size to decide upon the step size for perturbation as a significant oscillation of the MPP is observed. By employing the variable step sizes, the oscillations around the MPP and higher tracking time issues can be very well addressed, although the step size procurement strategy results in higher complexity. In the case of hybrid step sizes, step sizes of different types are generated. However, their operation order and their activation need accurate designing and add to the complexity. Optimizing generated step sizes by employing the simpler MPO methods can be seen as a promising research area to devise robust MPPT methods.

Author Contributions: Conceptualization, J.P. and P.N.; methodology, J.P.; software, J.P.; validation, J.P., P.N. and K.K.; formal analysis, J.P.; investigation, J.P.; resources, J.P.; data curation, J.P.; writingoriginal draft preparation, J.P.; writing—review and editing, J.P., P.N., K.K. and V.V.; visualization, J.P.; supervision, J.P.; project administration, J.P.and P.N.; funding acquisition, V.V. All authors have read and agreed to the published version of the manuscript.

Funding: This research received no external funding.

Institutional Review Board Statement: Not applicable.

Informed Consent Statement: Not applicable.

Data Availability Statement: Not applicable.

Acknowledgments: The authors would like to thank Symbiosis International (Deemed University) for the constant encouragement and support. 
Conflicts of Interest: The authors declare no conflict of interest.

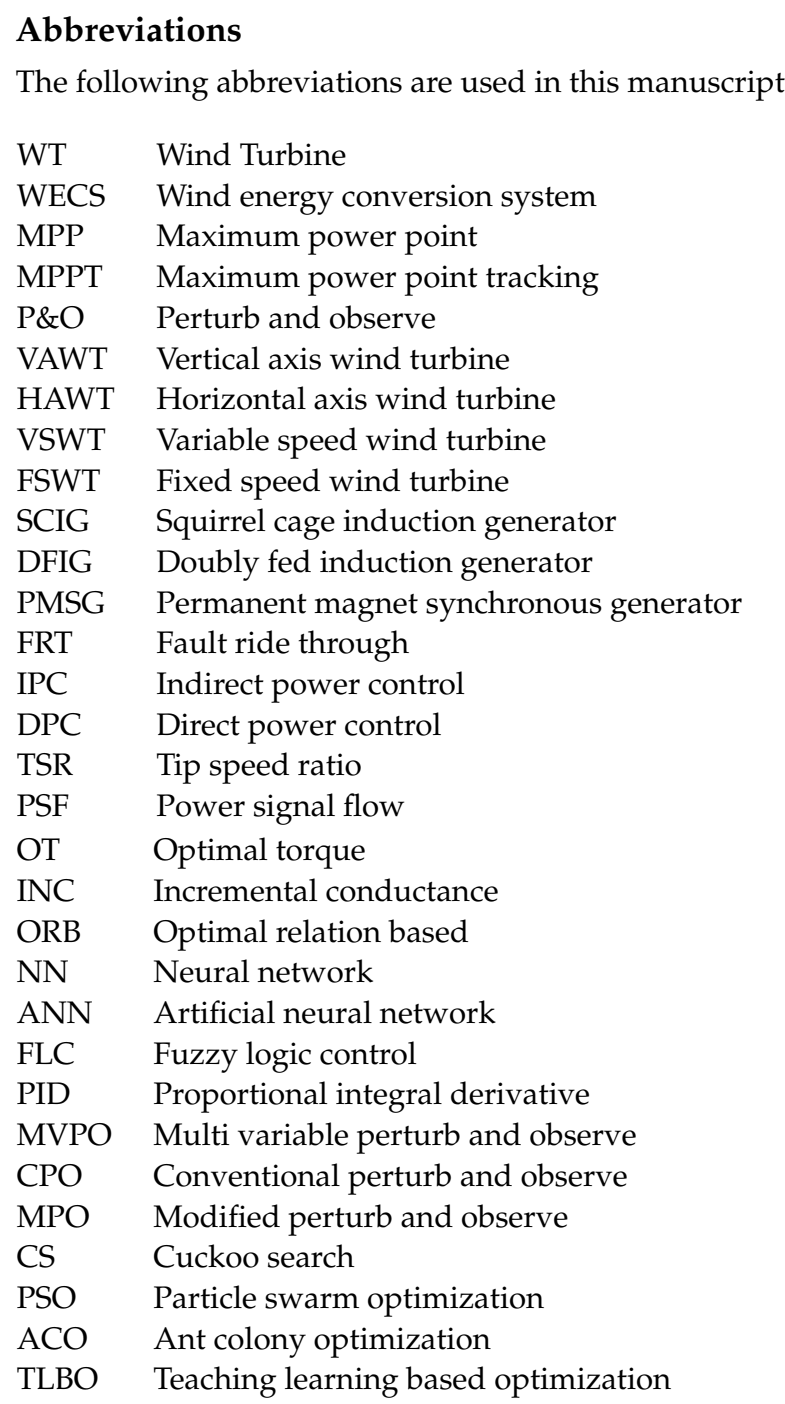

\section{References}

1. Hossain, M.M.; Ali, M.H. Future research directions for the wind turbine generator system. Renew. Sustain. Energy Rev. 2015, 49, 481-489. [CrossRef]

2. Aliyu, A.K.; Modu, B.; Tan, C.W. A review of renewable energy development in Africa: A focus in South Africa, Egypt and Nigeria. Renew. Sustain. Energy Rev. 2018, 81, 2502-2518. [CrossRef]

3. Mousa, H.H.H.; Youssef, A.R.; Mohamed, E.E.M. International Journal of Electrical Power and Energy Systems State of the art perturb and observe MPPT algorithms based wind energy conversion systems: A technology review. Int. J. Electr. Power Energy Syst. 2021, 126, 106598. [CrossRef]

4. Muyeen, S.M.; Takahashi, R.; Murata, T.; Tamura, J. A variable speed wind turbine control strategy to meet wind farm grid code requirements. IEEE Trans. Power Syst. 2010, 25, 331-340. [CrossRef]

5. Muljadi, E. Pitch-controlled variable-speed wind turbine generation. IEEE Trans. Ind. Appl. 2001, 37, 240-246. [CrossRef]

6. Mittal, R.; Sandhu, K.; Jain, D. An Overview of Some Important Issues Related to Wind Energy Conversion System (WECS). Int. J. Environ. Sci. Dev. 2010, 1, 351-363. [CrossRef]

7. Aslam Bhutta, M.M.; Hayat, N.; Farooq, A.U.; Ali, Z.; Jamil, S.R.; Hussain, Z. Vertical axis wind turbine-A review of various configurations and design techniques. Renew. Sustain. Energy Rev. 2012, 16, 1926-1939. [CrossRef]

8. Njiri, J.G.; Söffker, D. State-of-the-art in wind turbine control: Trends and challenges. Renew. Sustain. Energy Rev. 2016, 60, 377-393. [CrossRef]

9. Pao, L.Y.; Johnson, K.E. Control of Wind Turbines: Approaches, challenges, and recent developments. IEEE Control Syst. 2011, 31, 44-62. [CrossRef]

10. Duran, M.J.; Barrero, F.; Pozo-Ruz, A.; Guzman, F.; Fernandez, J.; Guzman, H. Understanding power electronics and electrical machines in multidisciplinary wind energy conversion system courses. IEEE Trans. Educ. 2013, 56, 174-182. [CrossRef] 
11. Cheng, M.; Zhu, Y. The state of the art of wind energy conversion systems and technologies: A review. Energy Convers. Manag. 2014, 88, 332-347. [CrossRef]

12. Singh, G.K. Self-excited induction generator research-A survey. Electr. Power Syst. Res. 2004, 69, 107-114. [CrossRef]

13. Patel, M.R. Wind and solar power systems: Design, analysis, and operation, second edition. Wind Sol. Power Syst. Des. Anal. Oper. Second Ed. 2005, 73069, 1-448. [CrossRef]

14. Kumar, D.; Chatterjee, K. Artificial bee colony based MPPT algorithm for wind energy conversion system. In Proceedings of the 2016 IEEE 6th International Conference on Power Systems (ICPS) 2016, New Delhi, India, 4-6 March 2016. [CrossRef]

15. Egea-Alvarez, A.; Junyent-Ferre, A.; Bergas-Jané, J.; Bianchi, F.D.; Gomis-Bellmunt, O. Control of a wind turbine cluster based on squirrel cage induction generators connected to a single VSC power converter. Int. J. Electr. Power Energy Syst. 2014, 61, 523-530. [CrossRef]

16. Rajaei, A.; Mohamadian, M.; Yazdian Varjani, A. Vienna-rectifier-based direct torque control of PMSG for wind energy application. IEEE Trans. Ind. Electron. 2013, 60, 2919-2929. [CrossRef]

17. Singh, M.; Chandra, A. Application of adaptive network-based fuzzy inference system for sensorless control of PMSG-based wind turbine with nonlinear-load-compensation capabilities. IEEE Trans. Power Electron. 2011, 26, 165-175. [CrossRef]

18. Chen, Z.; Guerrero, J.M.; Blaabjerg, F. A review of the state of the art of power electronics for wind turbines. IEEE Trans. Power Electron. 2009, 24, 1859-1875. [CrossRef]

19. Linus, R.M.; Damodharan, P. Maximum power point tracking and grid feeding of permanent magnet synchronous generator based wind energy conversion system using modified hill climb searching algorithm. India Int. Conf. Power Electron. IICPE 2012, 1-6. [CrossRef]

20. Zhang, Z.; Zhao, Y.; Qiao, W.; Qu, L. A space-vector-modulated sensorless direct-torque control for direct-drive PMSG wind turbines. IEEE Trans. Ind. Appl. 2014, 50, 2331-2341. [CrossRef]

21. Xie, D.; Lu, Y.; Sun, J.; Gu, C. Small signal stability analysis for different types of PMSGs connected to the grid. Renew. Energy 2017, 106, 149-164. [CrossRef]

22. Uehara, A.; Pratap, A.; Goya, T.; Senjyu, T.; Yona, A.; Urasaki, N.; Funabashi, T. A coordinated control method to smooth wind power fluctuations of a PMSG-Based WECS. IEEE Trans. Energy Convers. 2011, 26, 550-558. [CrossRef]

23. Mousa, H.H.; Youssef, A.R.; Mohamed, E.E. Variable step size P\&O MPPT algorithm for optimal power extraction of multi-phase PMSG based wind generation system. Int. J. Electr. Power Energy Syst. 2019, 108, 218-231. [CrossRef]

24. Mousa, H.H.; Youssef, A.R.; Mohamed, E.E. Modified P\&O MPPT algorithm for optimal power extraction of five-phase PMSG based wind generation system. SN Appl. Sci. 2019, 1. [CrossRef]

25. Watil, A.; El Magri, A.; Raihani, A.; Lajouad, R.; Giri, F. Multi-objective output feedback control strategy for a variable speed wind energy conversion system. Int. J. Electr. Power Energy Syst. 2020, 121, 106081. [CrossRef]

26. Errami, Y.; Ouassaid, M.; Maaroufi, M. A performance comparison of a nonlinear and a linear control for grid connected PMSG wind energy conversion system. Int. J. Electr. Power Energy Syst. 2015, 68, 180-194. [CrossRef]

27. Jadhav, H.T.; Roy, R. A comprehensive review on the grid integration of doubly fed induction generator. Int. J. Electr. Power Energy Syst. 2013, 49, 8-18. [CrossRef]

28. Hu, L.; Xue, F.; Qin, Z.; Shi, J.; Qiao, W.; Yang, W.; Yang, T. Sliding mode extremum seeking control based on improved invasive weed optimization for MPPT in wind energy conversion system. Appl. Energy 2019, 248, 567-575. [CrossRef]

29. Karabacak, M. A new perturb and observe based higher order sliding mode MPPT control of wind turbines eliminating the rotor inertial effect. Renew. Energy 2019, 133, 807-827. [CrossRef]

30. Dursun, E.H.; Kulaksiz, A.A. Second-order sliding mode voltage-regulator for improving MPPT efficiency of PMSG-based WECS. Int. J. Electr. Power Energy Syst. 2020, 121, 106149. [CrossRef]

31. Wu, A.; Zhao, B.; Mao, J.; Wu, B.; Yu, F. Adaptive active fault-tolerant MPPT control for wind power generation system under partial loss of actuator effectiveness. Int. J. Electr. Power Energy Syst. 2019, 105, 660-670. [CrossRef]

32. Kumar, D.; Chatterjee, K. A review of conventional and advanced MPPT algorithms for wind energy systems. Renew. Sustain. Energy Rev. 2016, 55, 957-970. [CrossRef]

33. Kazmi, S.M.R.; Goto, H.; Guo, H.J.; Ichinokura, O. Review and critical analysis of the research papers published till date on maximum power point tracking in wind energy conversion system. In Proceedings of the 2010 IEEE Energy Conversion Congress and Exposition (ECCE), Atlanta, GA, USA, 12-16 September 2010; Volume 1, pp. 4075-4082. [CrossRef]

34. Musunuri, S.; Ginn, H.L. Comprehensive review of wind energy maximum power extraction algorithms. IEEE Power Energy Soc. Gen. Meet. 2011. [CrossRef]

35. Abdullah, M.A.; Yatim, A.H.; Tan, C.W. A study of maximum power point tracking algorithms for wind energy system. In Proceedings of the 2011 IEEE 1st Conf. Clean Energy Technol. CET 2011, Kuala Lumpur, Malaysia, 27-29 June 2011; pp. 321-326. [CrossRef]

36. Abdullah, M.A.; Yatim, A.H.; Tan, C.W.; Saidur, R. A review of maximum power point tracking algorithms for wind energy systems. Renew. Sustain. Energy Rev. 2012, 16, 3220-3227. [CrossRef]

37. Kumar, M.B.; Saravanan, B.; Sanjeevikumar, P.; Blaabjerg, F. Review on control techniques and methodologies for maximum power extraction from wind energy systems. IET Renew. Power Gener. 2018, 12, 1609-1622. [CrossRef]

38. Ali, M.M.; Youssef, A.R.; Ali, A.S.; Abdel-Jaber, G.T. Variable step size PO MPPT algorithm using model reference adaptive control for optimal power extraction. Int. Trans. Electr. Energy Syst. 2020, 30, 1-21. [CrossRef] 
39. Heydari, M.; Smedley, K. Comparison of maximum power point tracking methods for medium to high power wind energy systems. In Proceedings of the 20th Electrical Power Distribution Conference (EPDC), Zahedan, Iran, 28-29 April 2015; pp. 184-189. [CrossRef]

40. Kazmi, S.M.R.; Goto, H.; Guo, H.J.; Ichinokura, O. A novel algorithm for fast and efficient speed-sensorless maximum power point tracking in wind energy conversion systems. IEEE Trans. Ind. Electron. 2011, 58, 29-36. [CrossRef]

41. Tan, K.; Islam, S. Optimum control strategies in energy conversion of PMSG wind turbine system without mechanical sensors. IEEE Trans. Energy Convers. 2004, 19, 392-399. [CrossRef]

42. Zhu, Y.; Cheng, M.; Hua, W.; Wang, W. A novel maximum power point tracking control for permanent magnet direct drive wind energy conversion systems. Energies 2012, 5, 1398-1412. [CrossRef]

43. Castelló, J.; Espí, J.M.; García-Gil, R. Development details and performance assessment of a Wind Turbine Emulator. Renew. Energy 2016, 86, 848-857. [CrossRef]

44. Ghaffari, A.; Krstić, M.; Seshagiri, S. Power optimization and control in wind energy conversion systems using extremum seeking. IEEE Trans. Control Syst. Technol. 2014, 22, 1684-1695. [CrossRef]

45. Taveiros, F.E.; Barros, L.S.; Costa, F.B. Back-to-back converter state-feedback control of DFIG (doubly-fed induction generator)based wind turbines. Energy 2015, 89, 896-906. [CrossRef]

46. Lahfaoui, B.; Zouggar, S.; Mohammed, B.; Elhafyani, M.L. Real Time Study of P\&O MPPT Control for Small Wind PMSG Turbine Systems Using Arduino Microcontroller. Energy Procedia 2017, 111, 1000-1009. [CrossRef]

47. Mei, Q.; Shan, M.; Liu, L.; Guerrero, J.M. A novel improved variable step-size incremental-resistance MPPT method for PV systems. IEEE Trans. Ind. Electron. 2011, 58, 2427-2434. [CrossRef]

48. Youssef, A.R.; Mousa, H.H.; Mohamed, E.E. Development of self-adaptive P\&O MPPT algorithm for wind generation systems with concentrated search area. Renew. Energy 2020, 154, 875-893. [CrossRef]

49. Balasundar, C.; Sudharshanan, S.; Elakkiyavendan, R. Design of an Optimal Tip Speed Ratio Control MPPT Algorithm for Standalone WECS. Int. J. Res. Appl. Sci. Eng. Technol. 2015, 3, 5.

50. Koutroulis, E.; Kalaitzakis, K. Design of a maximum power tracking system for wind-energy-conversion applications. IEEE Trans. Ind. Electron. 2006, 53, 486-494. [CrossRef]

51. Parker, C.M.; Leftwich, M.C. The effect of tip speed ratio on a vertical axis wind turbine at high Reynolds numbers. Exp. Fluids 2016, 57, 1-11. [CrossRef]

52. Nasiri, M.; Milimonfared, J.; Fathi, S.H. Modeling, analysis and comparison of TSR and OTC methods for MPPT and power smoothing in permanent magnet synchronous generator-based wind turbines. Energy Convers. Manag. 2014, 86, 892-900. [CrossRef]

53. Errami, Y.; Ouassaid, M.; Maaroufi, M. Optimal Power Control Strategy of Maximizing Wind Energy Tracking and Different Operating Conditions for Permanent Magnet Synchronous Generator Wind Farm. Energy Procedia 2015, 74, 477-490. [CrossRef]

54. Singh, J.; Ouhrouche, M. MPPT Control Methods in Wind Energy Conversion Systems. Fundam. Adv. Top. Wind Power 2011 [CrossRef]

55. Ganjefar, S.; Ghassemi, A.A.; Ahmadi, M.M. Improving efficiency of two-type maximum power point tracking methods of tip-speed ratio and optimum torque in wind turbine system using a quantum neural network. Energy 2014, 67, 444-453. [CrossRef]

56. Camblong, H.; de Alegria, I.M.; Rodriguez, M.; Abad, G. Experimental evaluation of wind turbines maximum power point tracking controllers. Energy Convers. Manag. 2006, 47, 2846-2858. [CrossRef]

57. Jena, D.; Rajendran, S. A review of estimation of effective wind speed based control of wind turbines. Renew. Sustain. Energy Rev. 2015, 43, 1046-1062. [CrossRef]

58. De Kooning, J.D.; Gevaert, L.; Van De Vyver, J.; Vandoorn, T.L.; Vandevelde, L. Online estimation of the power coefficient versus tip-speed ratio curve of wind turbines. IECON Proc. Ind. Electron. Conf. 2013, 1792-1797. [CrossRef]

59. Song, D.; Yang, J.; Cai, Z.; Dong, M.; Su, M.; Wang, Y. Wind estimation with a non-standard extended Kalman filter and its application on maximum power extraction for variable speed wind turbines. Appl. Energy 2017, 190, 670-685. [CrossRef]

60. Song, D.; Yang, J.; Fan, X.; Liu, Y.; Liu, A.; Chen, G.; Joo, Y.H. Maximum power extraction for wind turbines through a novel yaw control solution using predicted wind directions. Energy Convers. Manag. 2018, 157, 587-599. [CrossRef]

61. Sitharthan, R.; Karthikeyan, M.; Sundar, D.S.; Rajasekaran, S. Adaptive hybrid intelligent MPPT controller to approximate effectual wind speed and optimal rotor speed of variable speed wind turbine. ISA Trans. 2020, 96, 479-489. [CrossRef] [PubMed]

62. Yin, M.; Li, W.; Chung, C.Y.; Zhou, L.; Chen, Z.; Zou, Y. Optimal torque control based on effective tracking range for maximum power point tracking of wind turbines under varying wind conditions. IET Renew. Power Gener. 2017, 11, 501-510. [CrossRef]

63. Zhang, X.; Zhang, Y.; Hao, S.; Wu, L.; Wei, W. An improved maximum power point tracking method based on decreasing torque gain for large scale wind turbines at low wind sites. Electr. Power Syst. Res. 2019, 176, 105942. [CrossRef]

64. Mishra, S.; Shukla, S.; Verma, N.; Ritu, R. Comprehensive review on Maximum Power Point Tracking techniques: Wind Energy. In International Conference Communication, Control and Intelligent Systems; CCIS: Mathura, Uttar Pradesh, India, 2016; pp. 464-469. [CrossRef]

65. Oh, K.Y.; Park, J.Y.; Lee, J.S.; Lee, J.K. Implementation of a torque and a collective pitch controller in a wind turbine simulator to characterize the dynamics at three control regions. Renew. Energy 2015, 79, 150-160. [CrossRef] 
66. Liu, J.; Meng, H.; Hu, Y.; Lin, Z.; Wang, W. A novel MPPT method for enhancing energy conversion efficiency taking power smoothing into account. Energy Convers. Manag. 2015, 101, 738-748. [CrossRef]

67. Mirecki, A.; Roboam, X.; Richardeau, F. Comparative study of maximum power strategy in wind turbines. IEEE Int. Symp. Ind. Electron. 2004, 2, 993-998. [CrossRef]

68. Tripathi, S.M.; Tiwari, A.N.; Singh, D. Grid-integrated permanent magnet synchronous generator based wind energy conversion systems: A technology review. Renew. Sustain. Energy Rev. 2015, 51, 1288-1305. [CrossRef]

69. Xia, Y.; Ahmed, K.H.; Williams, B.W. A new maximum power point tracking technique for permanent magnet synchronous generator based wind energy conversion system. IEEE Trans. Power Electron. 2011, 26, 3609-3620. [CrossRef]

70. Tanaka, T.; Toumiya, T.; Suzuki, T. Output control by hill-climbing method for a small scale wind power generating system. Renew. Energy 1997, 12, 387-400. [CrossRef]

71. Datta, R.; Ranganathan, V.T. A method of tracking the peak power points for a variable speed wind energy conversion system. IEEE Trans. Energy Convers. 2003, 18, 163-168. [CrossRef]

72. Sachan, A.; Gupta, A.K.; Samuel, P. A review of MPPT algorithms employed in wind energy conversion systems. J. Green Eng. 2017, 6, 385-402. [CrossRef]

73. Houssamo, I.; Locment, F.; Sechilariu, M. Experimental analysis of impact of MPPT methods on energy efficiency for photovoltaic power systems. Int. J. Electr. Power Energy Syst. 2013, 46, 98-107. [CrossRef]

74. Mirbagheri, S.Z.; Mekhilef, S.; Mirhassani, S.M. MPPT with Inc.Cond method using conventional interleaved boost converter. Energy Procedia 2013, 42, 24-32. [CrossRef]

75. Urtasun, A.; Sanchis, P.; San Martín, I.; López, J.; Marroyo, L. Modeling of small wind turbines based on PMSG with diode bridge for sensorless maximum power tracking. Renew. Energy 2013, 55, 138-149. [CrossRef]

76. Kesraoui, M.; Korichi, N.; Belkadi, A. Maximum power point tracker of wind energy conversion system. Renew. Energy 2011, 36, 2655-2662. [CrossRef]

77. Carrillo, C.; Obando Montaño, A.F.; Cidrás, J.; Díaz-Dorado, E. Review of power curve modelling for windturbines. Reneww. Sustain. Energy Rev. 2013, 21, 572-581. [CrossRef]

78. Chinchilla, M.; Arnaltes, S.; Burgos, J.C. Control of permanent-magnet generators applied to variable-speed wind-energy systems connected to the grid. IEEE Trans. Energy Convers. 2006, 21, 130-135. [CrossRef]

79. Amei, K.; Takayasu, Y.; Ohji, T.; Sakui, M. A maximum power control of wind generator system using a permanent magnet synchronous generator and a boost chopper circuit. Proc. Power Convers. Conf. 2002, 3, 1447-1452. [CrossRef]

80. Morimoto, S.; Nakayama, H.; Sanada, M.; Takeda, Y. Sensorless output maximization control for variable-speed wind generation system using IPMSG. IEEE Trans. Ind. Appl. 2005, 41, 60-67. [CrossRef]

81. Pan, C.T.; Juan, Y.L. A Novel Sensorless MPPT Controller for a High-Efficiency Microscale Wind Power Generation System. IEEE Trans. Energy Convers. 2010, 25, 207-216. [CrossRef]

82. Zhang, H.B.; Fletcher, J.; Greeves, N.; Finney, S.J.; Williams, B.W. One-power-point operation for variable speed wind/tidal stream turbines with synchronous generators. IET Renew. Power Gener. 2011, 5, 99-108. [CrossRef]

83. Dalala, Z.M.; Zahid, Z.U.; Yu, W.; Cho, Y.; Lai, J.S. Design and analysis of an MPPT technique for small-scale wind energy conversion systems. IEEE Trans. Energy Convers. 2013, 28, 756-767. [CrossRef]

84. Abdullah, M.A.; Yatim, A.H.M. An online Optimum-Relation-Based Maximum Power Point Tracking Algorithm for Wind Energy Conversion System. In Proceedings of the Australasian Universities Power Engineering Conference, AUPEC 2014, Perth, Australia, 28 September-1 October 2014; Volume 27, pp. 1-6.

85. Li, H.; Shi, K.L.; McLaren, P.G. Neural-network-based sensorless maximum wind energy capture with compensated power coefficient. IEEE Trans. Ind. Appl. 2005, 41, 1548-1556. [CrossRef]

86. Burton, T.; Sharpe, D.; Jenkins, N.; Bossanyi, E. Wind Energy Handbook. Wind Energy 2001, 2, 471.

87. Fingersh, L.J.; Johnson, K.E. Baseline Results and Future Plans for the NREL Controls Advanced Research Turbine Preprint; National Technical Information Service (NTIS), U.S. Department of Commerce: Springfield, VA, USA, 2004.

88. Tes, V.S.; Fingersh, L.J.; Carlin, P.W. Results from the NiEL; National Technical Information Service (NTIS), U.S. Department of Commerce: Springfield, VA, USA, 1998.

89. Wang, Q.; Chang, L. An intelligent maximum power extraction algorithm for inverter-based variable speed wind turbine systems. IEEE Trans. Power Electron. 2004, 19, 1242-1249. [CrossRef]

90. Masood, B.; Siddique, M.S.; Asif, R.M. Maximum Power Point Tracking using Hybrid Perturb \& Observe and Incremental Conductance Techniques. In Proceedings of the 2014 4th International Conference on Engineering Technology and Technopreneuship (ICE2T), Kuala Lumpur, Malaysia, 27-29 August 2014.

91. Hosseini, S.H.; Farakhor, A.; Haghighian, S.K. Novel Algorithm of Maximum Power Point Tracking (MPPT) for Variable Speed PMSG Wind Generation Systems Through Model Predictive Control. In Proceedings of the 2013 8th International Conference on Electrical and Electronics Engineering (ELECO), Bursa, Turkey, 28-30 November 2013.

92. Punitha, K.; Devaraj, D.; Sakthivel, S. Artificial neural network based modified incremental conductance algorithm for maximum power point tracking in photovoltaic system under partial shading conditions. Energy 2013, 62, 330-340. [CrossRef]

93. Zammit, D.; Staines, C.S.; Micallef, A.; Apap, M.; Licari, J. Incremental Current Based MPPT for a PMSG Micro Wind Turbine in a Grid-Connected DC Microgrid. Energy Procedia 2017, 142, 2284-2294. [CrossRef] 
94. Yu, K.N.; Liao, C.K. Applying novel fractional order incremental conductance algorithm to design and study the maximum power tracking of small wind power systems. J. Appl. Res. Technol. 2015, 13, 238-244. [CrossRef]

95. Kortabarria, I.; Andreu, J.; Martínez de Alegría, I.; Jiménez, J.; Gárate, J.I.; Robles, E. A novel adaptative maximum power point tracking algorithm for small wind turbines. Renew. Energy 2014, 63, 785-796. [CrossRef]

96. Mousa, H.H.; Youssef, A.R.; Mohamed, E.E. Adaptive P\&O MPPT algorithm based wind generation system using realistic wind fluctuations. Int. J. Electr. Power Energy Syst. 2019, 112, 294-308. [CrossRef]

97. Youssef, A.R.; Ali, A.I.; Saeed, M.S.; Mohamed, E.E. Advanced multi-sector P\&O maximum power point tracking technique for wind energy conversion system. Int. J. Electr. Power Energy Syst. 2019, 107, 89-97. [CrossRef]

98. Hassan Abdou, E.; Youssef, A.R.; Kamel, S.; Aly, M. Sensor Less Proposed Multi Sector Perturb and Observe Maximum Power Tracking for 1.5 MW Based on DFIG Advanced control strategies for DFIG. J. Control Instrum. Eng. 2020. [CrossRef]

99. Mousa, H.H.; Youssef, A.R.; Essam, M. Improved Perturb and Observe MPPT Algorithm of Multi-Phase PMSG Based Wind Energy Conversion System. In Proceedings of the 2019 21st International Middle East Power Systems Conference (MEPCON), Cairo, Egypt, 17-19 December 2019; pp. 97-102. [CrossRef]

100. Gao, J.; Lu, J.; Huang, K.; Zhang, Y.; Huang, S. A novel variable step hill-climb search algorithm used for direct driven PMSG. In Proceedings of the 2009 International Conference Energy Environmental Technology ICEET 2009, Guilin, China, 16-18 October 2009; Volume 1, pp. 511-514. [CrossRef]

101. Nayanar, V.; Kumaresan, N.; Ammasai Gounden, N. A Single-Sensor-Based MPPT Controller for Wind-Driven Induction Generators Supplying DC Microgrid. IEEE Trans. Power Electron. 2016, 31, 1161-1172. [CrossRef]

102. Nateghi, A.R.; Karegar, H.K.; Bagheri, S. Maximum power point tracking of permanent magnet wind turbines equipped with direct matrix converter. J. Renew. Sustain. Energy 2014, 6. [CrossRef]

103. Mahdi, A.J.; Tang, W.H.; Wu, Q.H. Estimation of tip speed ratio using an adaptive perturbation and observation method for wind turbine generator systems. IET Conf. Publ. 2011, 2011, 84. [CrossRef]

104. He, L.; Li, Y.; Harley, R. Novel adaptive power control of a Direct-drive PM wind generation system in a micro grid. IEEE Power Electron. Mach. Wind Appl. 2012. [CrossRef]

105. Hong, C.M.; Chen, C.H.; Tu, C.S. Maximum power point tracking-based control algorithm for PMSG wind generation system without mechanical sensors. Energy Convers. Manag. 2013, 69, 58-67. [CrossRef]

106. Lin, W.M.; Hong, C.M. Intelligent approach to maximum power point tracking control strategy for variable-speed wind turbine generation system. Energy 2010, 35, 2440-2447. [CrossRef]

107. Elnaggar, M.; Abdel Fattah, H.A.; Elshafei, A.L. Maximum power tracking in WECS (Wind energy conversion systems) via numerical and stochastic approaches. Energy 2014, 74, 651-661. [CrossRef]

108. Nagarajan, K. A Predictive hill climbing algorithm for real valued multi-variable optimization problem like PID tuning. Int. J. Mach. Learn. Comput. 2018, 8, 14-19. [CrossRef]

109. Linus, R.M.; Damodharan, P. Maximum power point tracking method using a modified perturb and observe algorithm for grid connected wind energy conversion systems. IET Renew. Power Gener. 2015, 9, 682-689. [CrossRef]

110. Billel, M.; Abdallah, S.; Yassine, A. Maximum power extraction (SMC , P \& O) from wind energy system based on reliable control. Rev. Sci. Technol. 2015, 6, 70-84.

111. Meghni, B.; Ouada, M.; Saad, S. A novel improved variable-step-size P\&O MPPT method and effective supervisory controller to extend optimal energy management in hybrid wind turbine. Electr. Eng. 2020, 102, 763-778. [CrossRef]

112. Narayana, M.; Putrus, G.A.; Jovanovic, M.; Leung, P.S.; Mcdonald, S. Generic maximum power point tracking controller for small-scale wind turbines. Renew. Energy 2012, 44, 72-79. [CrossRef]

113. Fathabadi, H. Novel high efficient speed sensorless controller for maximum power extraction from wind energy conversion systems. Energy Convers. Manag. 2016, 123, 392-401. [CrossRef]

114. Mozafarpoor-Khoshrodi, S.H.; Shahgholian, G. Improvement of perturb and observe method for maximum power point tracking in wind energy conversion system using fuzzy controller. Energy Equip. Syst. 2016, 4, 111-122. [CrossRef]

115. Agarwal, V.; Aggarwal, R.K.; Patidar, P.; Patki, C. A novel scheme for rapid tracking of maximum power point in wind energy generation systems. IEEE Trans. Energy Convers. 2010, 25, 228-236. [CrossRef]

116. Mousa, H.H.; Youssef, A.R.; Mohamed, E.E. Hybrid and adaptive sectors P\&O MPPT algorithm based wind generation system. Renew. Energy 2020, 145, 1412-1429. [CrossRef]

117. Masood, N.A.; Yan, R.; Saha, T.K. A new tool to estimate maximum wind power penetration level: In perspective of frequency response adequacy. Appl. Energy 2015, 154, 209-220. [CrossRef]

118. Daili, Y.; Gaubert, J.P.; Rahmani, L. Implementation of a new maximum power point tracking control strategy for small wind energy conversion systems without mechanical sensors. Energy Convers. Manag. 2015, 97, 298-306. [CrossRef]

119. Yurdusev, M.A.; Ata, R. Assessment of optimum tip speed ratio in wind turbines using artificial neural networks. Energy 2006, 31, 2153-2161. [CrossRef]

120. Mullane, A.; Lightbody, G.; Yacamini, R. Adaptive Control of Variable Speed Wind Turbines. Rev. Energ. Ren. Power Eng. 2001, 101-110. Available online: https://www.cder.dz/vlib/revue/nspeciauxpdf/upec_13.pdf (accessed on 28 September 2021).

121. Hui, J.; Bakhshai, A.; Member, S.; Jain, P.K. A Sensor-less Adaptive Maximum Power Point Extraction Method with Voltage Feedback Control for Small Wind Turbines in Off-Grid Applications. IEEE J. Emerg. Sel. Top. Power Electron. 2015, 6777. [CrossRef] 
122. Zhao, Y.; Member, S.; Wei, C.; Member, S.; Zhang, Z.; Member, S. A Review on Position/Speed Sensorless Control for Permanent-Magnet Synchronous Machine-Based Wind Energy Conversion Systems. IEEE J. Emerg. Sel. Top. Power Electron. 2013.

123. Yang, B.; Zhang, X.; Yu, T.; Shu, H.; Fang, Z. Grouped grey wolf optimizer for maximum power point tracking of doubly-fed induction generator based wind turbine. Energy Convers. Manag. 2017, 133, 427-443. [CrossRef]

124. Rezk, H.; Fathy, A.; Abdelaziz, A.Y. A comparison of different global MPPT techniques based on meta-heuristic algorithms for photovoltaic system subjected to partial shading conditions. Renew. Sustain. Energy Rev. 2017, 74, 377-386. [CrossRef]

125. Mokhtari, Y.; Rekioua, D. High performance of Maximum Power Point Tracking Using Ant Colony algorithm in wind turbine. Renew. Energy 2018, 126, 1055-1063. [CrossRef]

126. Qais, M.H.; Hasanien, H.M.; Alghuwainem, S. Enhanced whale optimization algorithm for maximum power point tracking of variable-speed wind generators. Appl. Soft Comput. J. 2020, 86, 105937. [CrossRef]

127. Priyadarshi, N.; Ramachandaramurthy, V.K.; Padmanaban, S.; Azam, F. An ant colony optimized mppt for standalone hybrid pv-wind power system with single cuk converter. Energies 2019, 12, 167. [CrossRef]

128. Tiwari, R.; Babu, N.R. Fuzzy logic based MPPT for permanent magnet synchronous generator in wind energy conversion system. IFAC-PapersOnLine 2016, 49, 462-467. [CrossRef]

129. Fathabadi, H. Maximum mechanical power extraction from wind turbines using novel proposed high accuracy single-sensorbased maximum power point tracking technique. Energy 2016, 113, 1219-1230. [CrossRef]

130. Wei, C.; Zhang, Z.; Qiao, W.; Qu, L. Intelligent maximum power extraction control for wind energy conversion systems based on online Q-learning with function approximation. In Proceedings of the 2014 IEEE Energy Conversion Congress and Exposition (ECCE), Pittsburgh, PA, USA, 14-18 September 2014; pp. 4911-4916. [CrossRef]

131. Viveiros, C.; Melício, R.; Igreja, J.M.; Mendes, V.M.F. Supervisory control of a variable speed wind turbine with doubly fed induction generator. Energy Rep. 2015, 1, 89-95. [CrossRef]

132. Hui, J.; Member, I.S.; Bakhshai, A.; Member, I.S.; Jain, P.K.; Fellow, I. An Adaptive Approximation Method for Maximum Power Point Tracking ( MPPT ) in Wind Energy Systems. In Proceedings of the 2011 IEEE Energy Conversion Congress and Exposition, Phoenix, AZ, USA, 17-22 September 2011; pp. 2664-2669.

133. Galdi, V.; Piccolo, A.; Siano, P. Designing an Adaptive Fuzzy Controller for Maximum Wind Energy Extraction. IEEE Trans. Energy Convers. 2008, 23, 559-569. [CrossRef]

134. Liu, P.; Yang, W.T.; Yang, C.E.; Hsu, C.L. Sensorless wind energy conversion system maximum power point tracking using Takagi-Sugeno fuzzy cerebellar model articulation control. Appl. Soft Comput. 2015, 29, 450-460. [CrossRef]

135. Jaramillo-lopez, F.; Kenne, G.; Lamnabhi-lagarrigue, F. A novel online training neural network-based algorithm for wind speed estimation and adaptive control of PMSG wind turbine system for maximum power extraction. Renew. Energy 2016, 86, 38-48. [CrossRef]

136. Hong, C.M.; Ou, T.C.; Lu, K.H. Development of intelligent MPPT (maximum power point tracking) control for a grid-connected hybrid power generation system. Energy 2013, 50, 270-279. [CrossRef]

137. Assareh, E.; Biglari, M. A novel approach to capture the maximum power from variable speed wind turbines using PI controller, RBF neural network and GSA evolutionary algorithm. Renew. Sustain. Energy Rev. 2015, 51, 1023-1037. [CrossRef]

138. Nabipour, M.; Razaz, M.; Seifossadat, S.G.; Mortazavi, S.S. A new MPPT scheme based on a novel fuzzy approach. Renew. Sustain. Energy Rev. 2017, 74, 1147-1169. [CrossRef]

139. Yaakoubi, A.E.; Amhaimar, L.; Attari, K.; Harrak, M.H.; Halaoui, M.E.; Asselman, A. Non-linear and intelligent maximum power point tracking strategies for small size wind turbines: Performance analysis and comparison. Energy Rep. 2019, 5, 545-554. [CrossRef]

140. Medjber, A.; Guessoum, A.; Belmili, H.; Mellit, A. New neural network and fuzzy logic controllers to monitor maximum power for wind energy conversion system. Energy 2016, 106, 137-146. [CrossRef]

141. Brahmi, J.; Krichen, L.; Ouali, A. A comparative study between three sensorless control strategies for PMSG in wind energy conversion system. Appl. Energy 2009, 86, 1565-1573. [CrossRef]

142. Thongam, J.S.; Bouchard, P.; Beguenane, R.; Okou, A.F.; Merabet, A. Control of variable speed wind energy conversion system using a wind speed sensorless optimum speed MPPT control method. In Proceedings of the IECON 2011-37th Annual Conference of the IEEE Industrial Electronics Society, Melbourne, VIC, Australia, 7-10 November 2011; pp. 855-860. [CrossRef]

143. Phan, D.C.; Yamamoto, S. Rotor speed control of doubly fed induction generator wind turbines using adaptive maximum power point tracking. Energy 2016, 111, 377-388. [CrossRef]

144. Aubrée, R.; Auger, F.; Macé, M.; Loron, L. Design of an efficient small wind-energy conversion system with an adaptive sensorless MPPT strategy. Renew. Energy 2016, 86, 280-291. [CrossRef]

145. Ramos-Paja, C.; Saavedra-Montes, A.; Arango, E. Maximum power point tracking in wind farms by means of a multivariable algorithm. In Proceedings of the 2012 Workshop on Engineering Applications, Bogota, Colombia, 2-4 May 2012; pp. 1-6. [CrossRef]

146. Abdel-Salam, M.; Ahmed, A.; Abdel-Sater, M. Maximum power point tracking for variable speed grid connected small wind turbine. In Proceedings of the 2010 IEEE International Energy Conference, Manama, Bahrain, 19 May 2010; pp. 600-605. [CrossRef]

147. Merabet, A.; Islam, M.A.; Beguenane, R.; Trzynadlowski, A.M. Multivariable control algorithm for laboratory experiments in wind energy conversion. Renew. Energy 2015, 83, 162-170. [CrossRef] 
148. Azzouz, M.; Elshafei, A.L.; Emara, H. Evaluation of fuzzy-based maximum power-tracking in wind energy conversion systems. IET Renew. Power Gener. 2011, 5, 422-430. [CrossRef]

149. Chaicharoenaudomrung, K.; Areerak, K.; Areerak, K.; Bozhko, S.; Hill, C.I. Maximum Power Point Tracking for Stand-Alone Wind Energy Conversion System Using FLC -P\&O Method. IEEJ Trans. Electr. Electron. Eng. 2020. [CrossRef]

150. Ahmed, S.; Rashid, M.A.; Mohamed, S.B.; Yaakob, S.B. A Novel Maximum Power Point Tracking Algorithm for Wind Energy Conversion System. Eng. Lett. 2019, 27, 822-830.

151. Chen, J.; Lin, T.; Wen, C.; Song, Y. Design of a Unified Power Controller for Variable-Speed Fixed-Pitch Wind Energy Conversion System. IEEE Trans. Ind. Electron. 2016, 63, 4899-4908. [CrossRef]

152. Azzouz, S.; Messalti, S.; Harrag, A. A Novel Hybrid MPPT Controller Using (P\&O)-neural Networks for Variable Speed Wind Turbine Based on DFIG. Model. Meas. Control A 2019, 92, 23-29. [CrossRef]

153. Abdullah, M.A.; Al-Hadhrami, T.; Tan, C.W.; Yatim, A.H. Towards green energy for smart cities: Particle swarm optimization based MPPT approach. IEEE Access 2018, 6, 58427-58438. [CrossRef]

154. Vachon, W.A. Control of variable-speed wind turbines. Am. Soc. Mech. Eng. Sol. Energy Div. SED 1991, 11, 73-82.

155. Hussain, J.; Mishra, M.K. Adaptive Maximum Power Point Tracking Control Algorithm for Wind Energy Conversion Systems. IEEE Trans. Energy Convers. 2016, 31, 697-705. [CrossRef]

156. Sompracha, C.; Jayaweera, D.; Tricoli, P. Particle swarm optimisation technique to improve energy efficiency of doubly-fed induction generators for wind turbines. J. Eng. 2019, 2019, 4890-4895. [CrossRef] 